\title{
ProteCtING ENVIRONMENTALLY DISPLACED PERSONS UNDER THE KAMPALA CONVENTION: A BRIEF ASSESSMENT
}

\author{
ALFREDO DOS SANTOS SOARES \\ Research Member \\ Centro de Investigação \& Desenvolvimento sobre Direito e Sociedade \\ Universidade Nova de Lisboa \\ fedysantos@hotmail.com
}

Recibido: 9 de diciembre de 2017 / Aceptado: 15 de febrero de 2018

\begin{abstract}
The progressive geography of climate change is having an impact and the African continent is among one of the most vulnerable regions of the world. In line with the prediction of the Intergovernmental Panel on Climate Change in its first report (1990), the involuntary migration of populations is already proving to be one of the most serious impacts across this region. The greatest majority of victims remain in their own countries. Therefore, coupled with conflict, violence and development projects, slow-onset and rapid-onset disasters have currently made Africa home to the largest number of internally displaced people. Determined to tackle this plight, on $23^{\text {rd }}$ October 2009 the African Union adopted its Convention for the Protection and Assistance of Internally Displaced Persons in Africa (Kampala Convention), articulating the need for an integral response based on a combined framework of international human rights law and international humanitarian law. Five years after the convention entered into force (on $6^{\text {th }}$ December 2012), this paper aims to take stock of the progress made in its implementation and, in particular, assess its effectiveness in protecting people who are environmentally displaced due to climate change. The existing and ongoing normative, policy and institutional processes on domestication and implementation of the convention are identified and the degree to which these processes provide protection to people displaced by environmental disasters is explored, especially slow-onset impacts (e.g. desertification). The paper finds that, despite the remarkable efforts made to implement the said convention, the specific impact of its provisions for protecting and assisting environmental IDPs is still unperceivable. Much work remains to be done to translate this innovative instrument into practice, and


particularly to make specific improvements in the protection of IDPs due to disasters caused by climate change.

RESUMEN: La progresiva geografía de los impactos del cambio climático sitúa el continente africano entre las regiones más vulnerables del mundo. En línea con la predicción del Grupo Intergubernamental de Expertos sobre el Cambio Climático (IPCC) en su Primer Informe de 1990, la migración involuntaria de la población ya está demostrando ser uno de los impactos más graves en toda la región. La inmensa mayoría de las víctimas permanece en sus propios países, aunque no hay que subestimar la magnitud de cuantos se desplazan cruzando las fronteras estatales internacionalmente reconocidas. Así, pues, junto con los conflictos armados, las tensiones políticas y los llamados proyectos de desarrollo, los desastres ambientales súbitos y, máxime, los de realización lenta han convertido a África en el hogar del mayor número de personas desplazadas internamente (PDI). Decidida a hacer frente a esta difícil y acuciante realidad, la Unión Africana aprobó, el 23 de octubre de 2009, su Convención para la protección y asistencia de los desplazados internos en África (Convención de Kampala), en cuyas disposiciones se pone de manifiesto la necesidad de una respuesta holística, basada en un marco combinado de las normas internacionales de derechos humanos y el derecho internacional humanitario. Cinco años después de la entrada en vigor de la referida Convención (el 6 de diciembre de 2012), el presente trabajo se propone hacer balance de los progresos realizados en su aplicación y, en particular, evaluar su eficacia en la protección de las personas desplazadas por desastres ambientales, en el contexto del cambio climático. Con vistas en este objetivo, el texto intenta identificar los procesos normativos, políticos e institucionales existentes y en curso en torno a la domesticación e implementación de la convención. Intenta, asimismo, explorar el grado en que estos procesos propician la protección debida a las personas desplazadas por desastres ambientales, especialmente aquellos de aparición y realización lentas (v.g., la desertificación). A guisa de anticipación de las conclusiones de este trabajo, se señala que, no obstante los notables esfuerzos llevados a cabo hasta el momento en el sentido de la implementación de la susodicha convención, el impacto concreto de sus disposiciones sobre la mejora de la protección y la asistencia a las personas desplazadas internamente por los desastres ambientales sigue siendo imperceptible. Queda mucho trabajo por hacer para llevar a la práctica y hacer 
efectivo este innovador instrumento legal, en particular para asegurar la protección de las personas desplazadas por desastres en el contexto del cambio climático.

RESUM: La geografia progressiva dels impactes del canvi climàtic situa el continent africà entre les regions més vulnerables del món. En línia amb la predicció del Grup Intergovernamental d'Experts sobre el Canvi Climàtic (IPCC) en el primer informe de 1990, la migració involuntària de la població ja demostra que és un dels impactes més greus en tota la regió. La immensa majoria de les víctimes roman en els propis països, tot i que no cal subestimar la magnitud dels qui es desplacen i creuen les fronteres estatals reconegudes internacionalment. Així, doncs, juntament amb els conflictes armats, les tensions polítiques i els anomenats projectes de desenvolupament, els desastres ambientals sobtats i, màximament, els d'execució lenta, han convertit l'Àfrica en la llar del nombre més gran de persones desplaçades internament (PDI). Decidida a fer front a aquesta realitat difícil i apressant, la Unió Africana va aprovar, el 23 d'octubre de 2009, la Convenció per a la protecció i assistència dels desplaçats interns a l’Àfrica (Convenció de Kampala), les disposicions de la qual posen de manifest la necessitat d'una resposta holística, basada en un marc combinat de les normes internacionals de drets humans i el dret internacional humanitari. Cinc anys després de l'entrada en vigor d'aquesta Convenció (el 6 de desembre de 2012), aquest treball es proposa fer balanç dels progressos que s'han fet des que s'ha aplicat $i$, en particular, avaluar l'eficàcia en la protecció de les persones que s'han desplaçat a causa dels desastres ambientals, en el context del canvi climàtic. Amb vista en aquest objectiu, el text intenta identificar els processos normatius, polítics $\mathrm{i}$ institucionals existents $\mathrm{i}$ en curs al voltant de la domesticació i implementació de la convenció. Així mateix, intenta explorar el grau en què aquests processos propicien la protecció deguda a les persones que s'han desplaçat a causa de desastres ambientals, especialment els d'aparició i realització lentes (vg. la desertificació). A manera d'anticipació de les conclusions d'aquest treball, cal assenyalar que, malgrat els notables esforços que s'han dut a terme fins al moment en el sentit d'implementar la Convenció, l'impacte concret de les seves disposicions sobre la millora de la protecció i l'assistència a les persones desplaçades internament pels desastres ambientals continua imperceptible. Queda molta feina per fer per portar a la pràctica i fer efectiu aquest instrument legal innovador, en particular per assegurar la protecció de les persones desplaçades a causa dels desastres en el context del canvi climàtic. 
KEYWORDS: disasters - climate change - migration - States obligations - Kampala Convention.

PALABRAS CLAVE: desastres - cambio climático - migración - obligaciones de los Estados - Convención de Kampala.

PARAULES CLAU: desastres — canvi climàtic — migració - obligacions dels Estats - Convenció de Kampala.

SUMmARY: I. Introduction. II. The African Union context of internal displacement. 1. Approaching the dimension of African environmental displacement. 2. Scope of the Kampala Convention for the protection of environmental IDPs. a) The paradigm of State sovereignty as Responsibility to Protect IDPs. b) Key provisions for environmental IDPs. III. Approaching climate change and environmental displacement. 1. Looking at the links between climate change and displacement. 2. In search of an appropriate conceptual framework. a) "Environmental refugees". b) Alternative terminology. 3. Magnitude and amplitude of environmental displacement. 4. International recognition of environmentally displaced people. 5. International obligations of States under the legal regime on climate change. 6. Protecting environmentally displaced people: a pending issue. a) Internal environmentally displaced people. b) External environmentally displaced people. IV. The implementation of the Kampala Convention: are the environmental IDPs being protected? 1. Identifying good practices in domestication and implementation. 2. Are the environmental IDPs protected? V. Conclusion. VI. Bibliography.

\section{INTRODUCTION}

Unlike the visible flows of refugees and cross-border migrants to Europe, in recent years the plight of internally displaced persons (IDPs) has been largely neglected by the international community ${ }^{1}$. However, it is clearly a growing crisis and "a key challenge of our times"2. It is particularly severe in Africa, "a continent disproportionately affected by internal displacement"3 and home to the largest number of IDPs. In fact, as of the end of 2016, over 12.2 million people were living in displacement across the continent as a result of conflict and violence. That is more than 30 per cent of the global total (40.3 million) ${ }^{4}$. Added to this figure are the countless IDPs who are displaced due to development

\footnotetext{
${ }^{1}$ This is clearly reflected in the fact that IDPs "ended up largely excluded from the outcomes of the UN's Summit for Refugees and Migrants" held in September 2016. Indeed, "the single reference to IDPs in the New York Declaration pointed to links between internal displacement and large movements of migrants and refugees. However, addressing internal displacement was recognised mostly as a way of mitigating large cross-border movements of vulnerable people" (IDMC, Global Report on Internal Displacement, Geneva, May 2017 [hereinafter referred to as GRID 2017], p.5).

2 Idem.

${ }^{3}$ AFRICAN UNION, "Explanatory Note on the African Union Convention for the Protection and Assistance of Internally Displaced Persons in Africa", 2009 [online], p. 2.
}

${ }^{4}$ IDMC, GRID 2017, p.26. 
projects, sudden-onset disasters, such as floods, and slow-onset disasters, such as desertification and more frequent droughts, linked to the adverse effects of climate change. Indeed, while precise data are not available because they have not been collected systematically, it is easy to assume that the continent is also strongly impacted by displacement due to development projects and slow-onset disasters.

Concerned about internal displacement as "a source of suffering for millions of people, a driver of food insecurity and a barrier to the sustained development"s, African States showed their willingness and determination to address this problem in a comprehensive and detailed manner by adopting, on $23^{\text {rd }}$ October 2009, the African Union Convention for the Protection and Assistance of Internally Displaced Persons in Africa (Kampala Convention), which entered into force on $6^{\text {th }}$ December 2012. It was the fastest AU treaty to do so. It is the world's first and so far only legally binding regional instrument to cater specifically to IDPs.

Based on the premise that drivers of migration in general are not mono-causal but rather influenced by multiple factors, the Kampala Convention applies, in an integral way, to all situations of internal displacement regardless of their causes (Article 15). Although this makes complete sense, it does not preclude us from evaluating the extent to which implementation of the convention is being effective with regard to IDPs due to environmental disasters. In other words, the aim of this paper is to assess the current effectiveness of the Kampala Convention in providing protection to people displaced by disasters, linked to adverse effects of climate change. Among other reasons, this purpose is largely justified by the growing real affirmation of climate change, which tends to turn into the dominant force inducing human displacement ${ }^{6}$ because it operates as an amplifying factor for conflicts and other elements of socio-economic vulnerability, in particular on the African continent.

To fulfil this aim, methodological relevance is given to the conceptual analysis of disasters (explicitly referred to in the convention as one of the major drivers of internal displacement), as well as to identifying and analyzing the existing or under-construction policy, and legal and institutional national frameworks on environmental IDPs. In this

\footnotetext{
${ }^{5}$ IDMC, Africa report on internal displacement, Geneva, December 2016, p.4.

${ }^{6}$ RENAUD, Fabrice / BOGARDI, Janos J. / DUN, Olivia / WARNER, Koko, Control, Adapt or Flee. How to Face Environmental Migration?, Bonn: UNU-EHS, 2007, p.16.
} 
sense, we also place methodological emphasis on examining the measures taken or planned by State parties specifically to prevent and mitigate the effects of disasters, including establishing early warning systems and implementing disaster risk reduction strategies, emergency and disaster preparedness and management measures in areas at risk. We attempt to determine how all this is implemented to prevent displacement and protect people displaced by disasters, including those caused by climate change.

The paper is structured into three sections. The first section starts by providing an overview of the African context of forced displacement, with particular emphasis on characterizing internal displacement caused by disasters in the context of climate change. Then, it gives an outline of the convention's scope, drawing special attention to its key provisions on displacement due to disasters. The second section reviews and delves into the ongoing academic debate around the linkages between climate change and human mobility, as well as the evolution of the international response to displaced people's need for protection as a result of severe impacts due to climate change. The third and final section discusses the domestication and implementation process of the Kampala Convention, seeking to ascertain its current and future incidence and effectiveness in protecting environmental IDPs.

\section{THE AFRICAN UNION CONTEXT OF INTERNAL DISPLACEMENT}

As Adepoju emphasized ${ }^{7}$, Africa is aptly described as a moving continent, experiencing all the migratory configurations. Although fragmented, fluid, and often inaccurate, available migration data reveal that the African migration reality is essentially internal, intraregional, and follows a south-south movement. That is to say, the common denominator of the three most visible migratory configurations (labor migration, refugee flow and internal displacement) is that they are confined to the continent, including refugees and migrants who move to neighboring countries and IDPs who stay in their respective countries.

\footnotetext{
7 ADEPOJU, Aderanti, "Migration Dynamics, Refugees and Internally Displaced Persons", UNAI, 20 September 2016 [online] (retrieved 9.12.2017).
} 
At the end of 2016, the African continent was home to the greatest number of IDPs (over 13 million $)^{8}$ by conflict, violence and sudden-onset disasters, and thus it is facing an internal displacement crisis that is far greater than in any other region of the world.

According to $\mathrm{IDMC}^{9}$, among disasters triggered by rapid-onset natural hazards, flooding is by far the most significant cause of flight in the continent, accounting for more than 90 per cent of displacement associated with disasters every year since 2009. However, this same institution reveals that these estimates are in fact only partial, since a complete picture of the African internal displacement cannot be achieved without taking into account its other two important drivers, which have so far been largely ignored or less contemplated. We are referring to development projects (including the growing land grabbing) and slowonset disasters, mainly droughts and the resulting food insecurity. The lack of accurate quantitative systematically-collected data on displacement due to these two drivers makes it difficult to determine the real dimensions of the situation in the region.

\section{Approaching the dimension of African environmental displacement}

As we will discuss later in this paper, pending better and more comprehensive scientific evidence that may lead to a greater understanding of climate change in its complexity and also to a clear need for a strong will to mitigate the impact of human activity on the planet, responses to questions about the magnitude and amplitude of global and regional environmental displacement are nothing but mere approximations. Even so, some of these responses are already extremely worrying.

In line with the $\operatorname{IPCC}^{10}$, which clearly states that anthropogenic climate change is accelerating and is already having serious impacts on the environment and people's lives, the humanitarian community notes that this is verifiable in the frequency, intensity and severity of disasters. In this sense, it is estimated that disasters have doubled over the last four decades, rising from about 200 to more than 400 a year, most of them related to climate change. As a result, the total number of people directly affected by disasters during

\footnotetext{
${ }^{8}$ Excluding the north, the rest of the continent accounted for 12.2 million IDPs by conflict and violence, and 1.0 million by disasters by the end of 2016, says IDMC, GRID 2017, pp. 26 and 37.

${ }^{9}$ IDMC, Africa report on internal displacement, Geneva, December 2016, p.5.

${ }^{10}$ IPCC, Climate Change 2014: Synthesis Report. Contribution of Working Groups I, II and III to the Fifth Assessment Report of the Intergovernmental Panel on Climate Change [Core Writing Team, R.K. Pachauri and L.A. Meyer (eds.)], Geneva, 2014.
} 
the 1990s tripled to an average of 211 million people each year. In 2016 alone, 445 million people were reported to be affected by disasters ${ }^{11}$. Economic losses amount to 83 billion dollars a year ${ }^{12}$. Needless to say, many of those affected are, or become, displaced persons. Therefore, all this seems to indicate that, due to growing climate change impacts, along with increasingly intense and frequent disasters, environmental displacement is shaping the "new normality" of our world, especially on the African continent.

In fact, the general quantitative data available all place the African region among the most vulnerable, despite being the area that emits far less carbon dioxide than any other continent. As illustrated bellow (Figure 1), Africa's carbon dioxide (CO2) emissions per year are only a small fraction, 3\%, of the global emissions, yet Africa hosts $15 \%$ of the population of the world. Moreover, this continent accounts for only 3\% of world energy consumption, which means that the average energy consumption of an African inhabitant is six times less than that recorded for individuals of the other populations of the world ${ }^{13}$.

Figure 1: $\mathrm{CO} 2$ emissions by regions

\footnotetext{
11 This figure was made public during the Global Platform for Disaster Risk Reduction, held in Cancun, Mexico, 22-26 May, 2017, under the slogan "From Sendai to Cancun, From Commitment to Action".

${ }^{12}$ As indicated in the letter from the IASC Principals to Yvo de Boer, Executive Secretary of the United Nations Framework Convention on Climate Change, 30 April 2009, http://www.humanitarianinfo.org/iasc (retrieved 9.12.2017).

13 RUPPEL, Oliver C., "Climate Change Law and Policy Positions in the African Union and Related Developments in Selected African Countries", in Ruppel, Oliver C. / Roschmann, Christian / RuppelSchlichting, Katharina (Eds.), Climate Change: International Law and Global Governance Volume II: Policy, Diplomacy and Governance in a Changing Environment, Baden-Baden: Nomos, 2013, pp.411-412.
} 

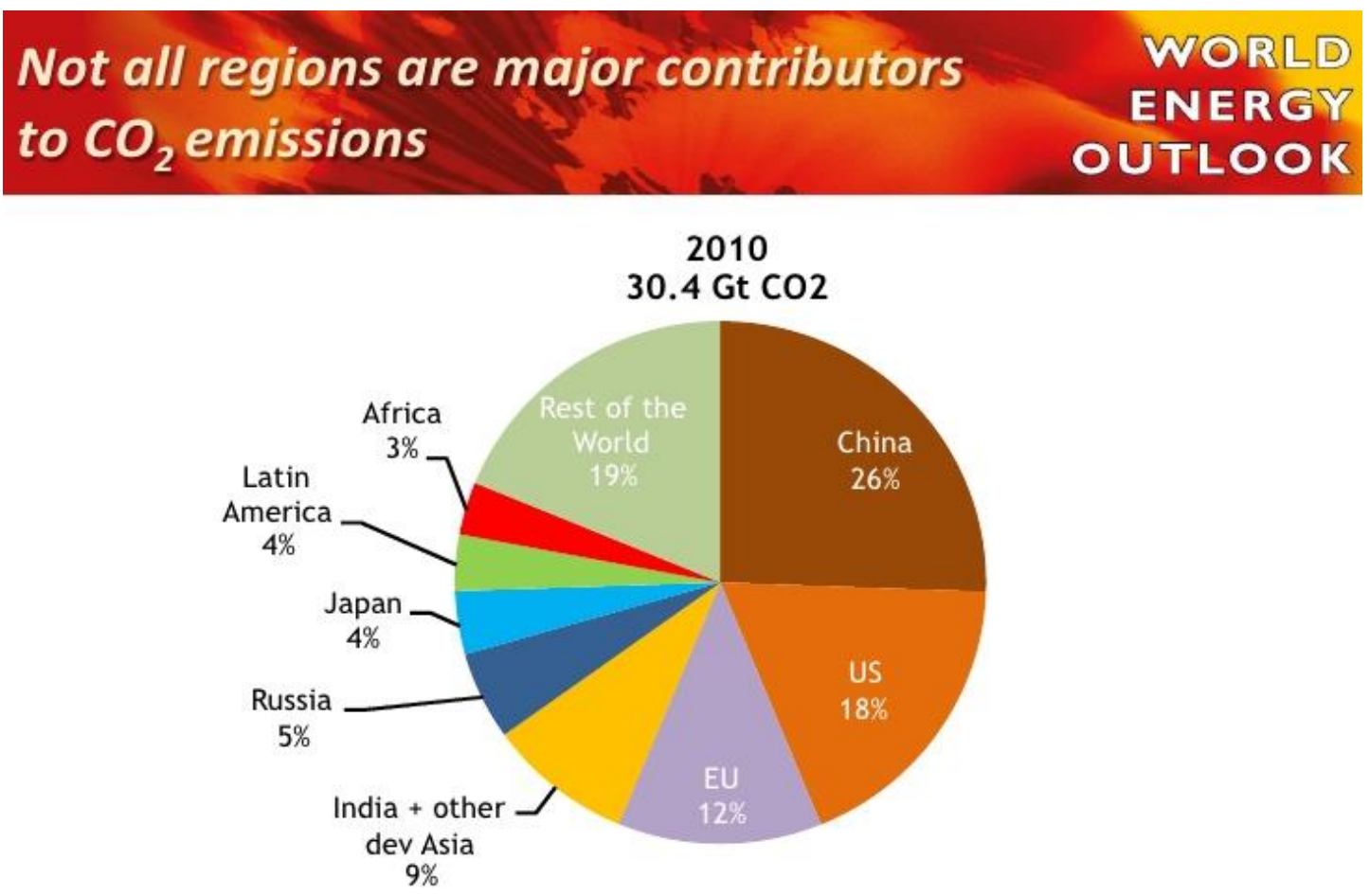

Africa constitutes $15 \%$ of the global population, but just $3 \%$ of global $\mathrm{CO}_{2}$-emissions

Source: Fatih Birol ${ }^{14}$

Similarly, in 2007 the IPCC $^{15}$ reported on the effects of climate change that trigger displacement, and pointed to the African continent as among the regions that could be most affected by water stress - both its scarcity (desertification) and its excess (floods, sea level rise, tropical cyclones) - and food insecurity and hunger, as a consequence of the decrease in crop yields. Recently, the IDMC pointed out that although no African countries were among the 10 to experience the largest-scale or relatively largest-scale displacement in 2016, "significant sudden-onset disasters did occur, however, and the displacements they triggered compounded the impacts of other natural and man-made hazards, including drought, coastal erosion, land degradation and conflict". This same institution concludes their report clearly stating that if displacement associated with slowonset disasters was included in their estimates, particularly those related to drought

\footnotetext{
${ }^{14}$ BIROL, Fatih, "Global Energy Outlook and the Implications for Africa”, presentation in Paris, 25 April $2012<$ https://es.slideshare.net/internationalenergyagency/birol-18th-meeting-of-the-africa-partnershipforum> (retrieved 9.12.2017).

15 IPCC, Cambio climático 2007: Informe de síntesis. Contribución de los Grupos de trabajo I, II y III al Cuarto Informe de evaluación del Grupo Intergubernamental de Expertos sobre el Cambio Climático [Equipo de redacción principal: Pachauri, R.K. y Reisinger, A. (directores de la publicación)], Ginebra, 2007.
} 
conditions and food insecurity, the displacement figures for Africa would be significantly higher than they are right now ${ }^{16}$.

Outside IDMC and in an attempt to quantify this pressing reality, some estimations ${ }^{17}$ indicate that in the coming decades, disasters related to climate change may put at risk around 80 to 120 million people on the African continent. Certain sub-regions, in particular the Sahara and semi-arid areas in Southern Africa, may suffer from a temperature increase of 1.6 degrees by 2050. In the Horn of the Africa region rainfall may decline to about $10 \%$. It should also be noted that around $50 \%$ of the African population lives in dry regions susceptible to drought. As Jean Ping pointed out ${ }^{18}$, the phenomenon of desertification in Africa is extremely disturbing, affecting $43 \%$ of productive land, which is equivalent to $70 \%$ of activity and $40 \%$ of the continent's population. In addition, the sea level could increase by around 25 centimeters, jeopardizing lowlands of the western part of the continent and coastal fishing banks. The economies of a large part of the African population are thus highly exposed to all these climate change impacts, which interact with sociopolitical factors, accentuating their vulnerability ${ }^{19}$. Taking all this into account, the Food and Agriculture Organization of the United Nations (FAO) has predicted that, "by 2080 , due to climate change, it is likely that $75 \%$ of the African population will be at risk of hunger" 20 .

Therefore, if ongoing trends are not reversed, forced displacement caused by disasters related to climate change is likely to increase exponentially over the second half of this century. As for the orientation, as this displacement is predominantly internal (subregional at most), only a small number of affected people are able to undertake a transcontinental migration ${ }^{21}$. However, some "alarmist" estimations insist that, by 2020 , some 60 million Africans will move from southern regions to northern Africa and Europe

\footnotetext{
${ }^{16}$ IDMC, GRID 2017, p.38.

17 SOLÀ PARDELL, Oriol, Desplazados medioambientales: una nueva realidad, Bilbao: Universidad de Deusto, 2012, pp.27-28.

${ }^{18}$ Quoted in "Desertificação afecta a economia", Jornal de Angola, edición de 26.10.2011.

${ }^{19}$ SOLÀ PARDELL, Oriol, Desplazados medioambientales, op.cit, pp.27-28.

${ }^{20}$ Statement available at http://www.climdev-africa.org/content/fact (retrieved 9.12.2017).

${ }^{21}$ IASC, "Climate Change, Migration and Displacement: Who Will Be Affected?" Working Paper submitted to UNFCCC Secretariat by the informal group on Migration/Displacement and Climate Change of the InterAgency Standing Committee, 31 October 2008 <http://unfccc.int/resource/docs/2008/smsn/igo/022.pdf> (retrieved 9.12.2017).
} 
to flee the adverse effects of climate change ${ }^{22}$.

Conscious of internal displacement as a source of suffering and specific vulnerability for millions of people, a driver of continuing instability, food insecurity and a barrier for human and sustainable development, the Heads of State and Government of Member States of the African Union showed their willingness, commitment and determination to address such a challenging situation by establishing an appropriate legal and comprehensive binding framework for the protection of and assistance for IDPs across the region: the Kampala Convention.

\section{Scope of the Kampala Convention fo- the protection of environmental IDPs a) The paradigm of State sovereignty as Responsibility to Protect IDPs}

Unanimously celebrated as a ground-breaking convention, the first and so far only regional legally-binding instrument for the protection and assistance of IDPs is based on the new legal, political and ethical paradigm from which premise the AU aims to address forced displacement: the "Responsibility to Protect" (R2P) principle.

It should be recalled, in this sense, that the change from the Organization of African Unity (OAU) to the African Union (AU), in 2000, represented a significant qualitative leap in the goals and orientation of the pan-African organization, which decided to shift from a non-interference to a non-indifference-based attitude. This led to R2P being taken up as the appropriate paradigm for handling the continent's enormous challenges, forced migration included.

At this point, it is worth remembering that, aversely to the trend to dissociate internally displaced people and the R2P, excluding them from the conceptual and operational scope of this emerging international regulation, the AU reaffirms the historical and factual proximity between the need for protection of IDPs and the R2P principle. The Kampala Convention represents a qualitative contribution coming from the pan-African organization to the doctrinal and normative development of State sovereignty assumed as R2P. The maximum regional normative expression in this regard is outlined in Articles 4 (h) (j) and 23.2 of the AU Constitutive Act. The two articles constitute the cornerstone of the African system for the protection of populations in danger, including IDPs. Thus, the

\footnotetext{
22 "ONG reclaman que se reconozca a los 'desplazados ambientales", diario www.elmundo.es, edition of
} 21/05/2010. 
Constitutive Act establishing the AU (2000) has turned into the first international treaty to stipulate the obligation and responsibility for regional and international organizations to intervene in a particular member State in order to assure human protection. Therefore, the above mentioned Article 4 of the AU Constitutive Act, clearly reflected in Article 8 of the Kampala Convention, represents, at least on paper, a significant endpoint in the evolution of international discussions on the so-called "right to humanitarian intervention".

With that said, it is opportune to mention that, from the chronological perspective, the first formal collective manifestation of the R2P paradigm took place at the Great Lakes subregional level, through its incorporation into the Great Lakes Pact (2006). Thanks to its Protocol on the Protection and Assistance of Internally Displaced Persons, this Pact became the first multilateral instrument in the world to commit States to adopting the United Nations Guiding Principles on Internal Displacement (1998) $)^{23}$ as a legally binding instrument. In this sense, this sub-regional legal instrument proved to be an authentic embryonic experience for the Kampala Convention and its R2P approach ${ }^{24}$. Similarly to the above mentioned Protocol, the Kampala Convention is based on the premise that the State's primary responsibility is to address internal displacement and it incorporates the Guiding Principles on Internal Displacement directly. However, it goes beyond the Guiding Principles because it articulates the need for an integral response to internal displacement based on a combined framework of international human rights law and international humanitarian law, as Chaloka Beyani argued ${ }^{25}$.

As mentioned above, in its introduction the Kampala Convention clearly recognizes that in addition to generating specific suffering and vulnerability for the victims, displacement caused by natural or man-made disasters, including climate change, has a devastating impact on human life, peace, stability, security and the development of the continent. The Convention therefore encourages the exercise of national sovereignty as R2P, it also fosters collective responsibility at the regional, international and global levels for the sake of a new solidarity, as a sine qua non strategy to successfully deal with adverse climate change impacts on human life and mobility.

\footnotetext{
${ }^{23}$ E/CN.4/1998/53/Add.2, annex.

${ }^{24}$ About the similarities and differences between the two instruments, see INTERNATIONAL REFUGEE RIGHTS INITIATIVE, Comparison of the Kampala Convention and the IDP Protocol of the Great Lakes Pact. A briefing note by the International Refugee Rights Initiative, January 2014 [available online] (retrieved 9.12.2017).
}

${ }^{25} \mathrm{~A} / \mathrm{HRC} / 26 / 33$. 


\section{b) Key provisions for environmental IDPs}

The conceptual scope of environmental IDPs can be found within the general definition of IDPs, outlined in Article $1(\mathrm{~K})$ and (I) of this Convention. Environmental IDPs qualify as a subcategory of

"persons or groups of persons who have been forced or obliged to flee or to leave their homes or places of habitual residence, in particular as a result of or in order to avoid the effects of armed conflict, situations of generalized violence, violations of human rights or natural or human-made disasters, and who have not crossed an internationally recognized State border".

Those persons who move with anticipation to avoid the effect of disasters, both suddenonset (e.g. floods) and slow-onset (e.g. droughts and soil degradation), also qualify as environmentally displaced people. Moreover, environmental IDPs and, therefore, those subject to the Convention, are likewise those people displaced as a result of the State's adaptational measures, such as evacuations or relocations, as stated in Article 1(1), especially when such measures are arbitrary. Thus, in its Article 4(4)f, the convention even goes further by clearly defining as arbitrary any "forced evacuation in cases of natural or human made disasters or other causes if the evacuations are not required for the safety or health of those affected".

Under Article 5(4) of the convention, State parties are required to take measures to protect and assist people displaced by natural or human-made disasters, including those caused by climate change. In areas of potential displacement, these measures include the States parties using continental early warning systems, as well as establishing and implementing disaster risk reduction strategies, emergency and disaster preparedness and management measures. States are also required to provide immediate protection and assistance to IDPs where necessary. This also means that the State's responsibility for preventing environmental displacement implies that appropriate legislation and policies are adopted, a national focal point is designated, and necessary funds are allocated for protection and assistance, without prejudice to international support.

In addition to the above, States should assess or facilitate the assessment of the needs and vulnerabilities of displaced populations and host communities. This task requires a national registry of victims and areas at risk. The set of national preventive measures must 
be harmonized with the AU's warning system, which is planned to be developed under Article 13 of AU Constitutive Act.

State responsibility in the context of environmental displacement also includes the adoption of special measures to ensure protection against environmental degradation, the obligation to treat victims without discrimination and to respect their right to seek safety elsewhere inside or outside the country. All this is closely related to displacement induced by so-called "development projects", carried out both by public authorities and private agents. However, the significant development-based displacement occurring in Africa is yet to gain prominence in the international media and political agenda. Indeed, even though this root cause of internal displacement prevails in many African countries, it has largely gone unnoticed in discussions on humanitarian protection by regional and international agencies ${ }^{26}$. Worse still, the States and multinational companies are showing political resistance to addressing this pressing problem.

Under the convention, States must conduct the necessary environmental impact assessment before a particular project is undertaken. With regard to arbitrary displacement, special attention should be given to civil liability of multinational enterprises and other non-state actors, in particular those whose activities in extracting and exploiting economic and natural resources may degrade the environment and, consequently, generate displacements (Article 3 h.).

Furthermore, by analogy to the non-refoulement principle, forced return or resettlement is prohibited, especially to places where, due to environmental reasons, people's life, safety, freedom and health may be at risk. On the contrary, States must promote and create satisfactory conditions for voluntary return, local integration or relocation on a sustainable basis and in circumstances of safety and dignity.

Similarly, effective protection measures to be taken by States must include the establishment of an adequate legal framework in accordance with international standards, providing fair and equitable compensation and other forms of reparation to people affected by damages in the wake of displacement. In this regard, the State's obligation of due diligence is of the utmost importance, since the State must assume responsibility for the reparation and compensation that people receive for displacement and damages as a result

\footnotetext{
26 ADEOLA, Romola, "What does development-caused displacement look like in Africa?", IDMC,
} December 2016 [online] (retrieved 9.12.2017). 
of negligence and inaction of public authorities in relation to the prevention of predictable disasters. Similarly, in accordance with Article 12(2), State parties are liable for compensating IDPs for damages when a given State party does not protect and assist IDPs in the event of disasters due to natural hazards. This provision is particularly relevant with regard to assets left behind by IDPs, for which Article 9(2)(i) requests State parties to take necessary protective measures.

At this point and in line with a number of analysts, it is worthwhile noting that, despite being an instrument shaped to regulate internal displacement including that motivated by disasters related to climate change, the Kampala Convention may have indirect implications for the protection and assistance of environmental externally-displaced people. Certainly, the vacuum will persist in this regard both in the international and the AU regional arenas. However, the Kampala Convention may represent an initial step towards establishing the much-needed international legal policy and institutional framework for the protection and assistance of those environmentally displaced people who manage to cross an internationally recognized State border. We will get back to this aspect later. Meanwhile, the next section will give an overview of the international academic debate on displacement in the context of climate change, which may help to clarify the necessary theoretical framework for assessing the Kampala Convention in protecting IDPs due to disasters and climate change.

\section{APPROACHING CLIMATE CHANGE AND ENVIRONMENTAL DISPLACEMENT}

Climate change has been characterized by the former UN General Secretary Ban Ki-moon as "the defining challenge of our era" 27 . As such, it affects directly or transversely all areas of human living, being at the same time a study subject for many scientific and academic disciplines. One of the key questions for many of them deals with the impact that climate change has or may have on human mobility.

\section{Looking at the links between climate change and displacement}

In recent times, in particular since 2000, Mozambique has experienced an unusual increase

27 “Climate change poses 'defining challenge' of our time, Ban says", UN News Centre, 7 October 2008 [online] (retrieved 7.12.2017). 
in the frequency and intensity of floods with tragic consequences, the last of which occurred in January 2013. Both national authorities and victims attribute this increase to global warming ${ }^{28}$. Similarly, floods that devastated Pakistan between July and August 2010 have been widely considered a sign of extreme weather events that the entire region may suffer more frequently in the future due to climate change ${ }^{29}$. Aligned with this perception are the peasants of eastern Madagascar, who feel unable to cope with the increasingly destructive storms (and cyclones) devastating their crops and homes ${ }^{30}$, as well as those of the Horn of Africa and southern Africa, continuously affected by the scarcity of rainfall, desertification and soil degradation ${ }^{31}$. At the same time, the inhabitants of several small island states, especially atolls (Kiribati, Maldives, Marshall Islands, Tokelau and Tuvalu), do not hesitate to attribute to climate change the rise in the sea level, which could lead to the disappearance of their countries and irrevocably reduce them to statelessness.

It should be emphasized that all of the environmental events mentioned above involve population displacement. This leads us to make a brief overview of the ongoing debate on the causal links between these disasters and climate change. However, first it is necessary to point out the existence of persistent scientific disagreement, sometimes polarized, on anthropogenic climate change. Immersed in heated discussions, advocates and detractors accuse each other of "climate-skepticism" perceived as "business lobbying" serving the fossil fuel industry (oil, coal and natural gas); and of "science fiction" and "eco-alarmism" of those who have allegedly turned climate change into a summary of all problems affecting humanity ${ }^{32}$.

Obviously, both agree on the apodictic recognition of change as something inherent to

${ }^{28}$ INGC, Main report: INGC Climate Change Report: Study on the impact of climate change on disaster risk in Mozambique, [Asante, K., Brito, R., Brundrit, G., Epstein, P., Fernandes, A., Marques, M.R., Mavume, A, Metzger, M., Patt, A., Queface, A., Sanchez del Valle, R., Tadross, M., Brito, R. (eds.)], Mozambique: INGC, 2009.

${ }^{29}$ GMF, Report: Climate-induced migration growing problem for nations of all kind, Washington, 29 September 2010 [online] (retrieved 9.12.2017).

30 KÄLIN, Walter, Climate Change Displacement - A Challenge for International Law, Kolkata, Mahanirban Calcutta Research Group [online] (retrieved 9.12.2017).

${ }^{31}$ HEINRICH BÖLL STIFTUNG, Climate Governance in Africa. Adaptation Strategies and Institutions, Cape Town: Unity Press, 2010.

${ }^{32}$ SANZ DONAIRE, Juan José, "Precisiones a las bases científicas del cambio climático", en Centro Superior De Estudios De La Defensa Nacional (Ed.), Cambio climático y su repercusión en la economía, la seguridad y la defensa, Madrid: Ministerio de Defensa, 2009, p.11; GODREJ, Dinyar, El cambio climático, Barcelona: Intermón Oxfam, 2002, pp.90-97. 
planet Earth which, over its millions of years of existence, has undergone enormous and intense mutations. The difficulty arises when humans are considered as responsible for some of these changes. However, there are many scientists who consider that human activity has an effect on the global climate, arguing that human beings have the real capacity to directly affect the climate system, as evidenced by the massive emissions of greenhouse gases resulting from the use of fossil fuels. Therefore, they assert that there is clear evidence that links this increasing emission of gases to the atmosphere over the 20th century with the consequent increase in the average global temperature, which, according to them, has been rising since the 1970s, and may have undergone an additional acceleration over the first decade of the 21 st century ${ }^{33}$.

We cannot ignore the great uncertainties surrounding a reality of such dizzying complexity like the climate and the processes of its variability, nor the need to resort to prudence and rigorous and deep analysis, which can lead to greater scientific evidence, and shed more light on the subject, favoring its better understanding and adequate management. In any case, here we do not only share the perception that the climate is changing, but also, and above all, the scientific certainty that endeavors to demonstrate that anthropogenic climate change is a reality in which we are already immersed, not a mere speculation concerning a remote future ${ }^{34}$. This is, after all, the major conclusion that the IPCC reached in its fifth assessment report, asserting that climate change is unequivocal, along with the human influence and responsibility for $\mathrm{it}^{35}$.

By many considered as one of the major threats facing humanity along with terrorism and nuclear proliferation ${ }^{36}$, and one of the four forces that are to determine the future of civilization $^{37}$, climate change entails serious dangers and terrifying consequences that, in many regions, might be of cataclysmic dimensions, especially if global warming, instead

\footnotetext{
${ }^{33}$ DUARTE, Carlos. M. (Coord.) et al., Cambio global. Impacto de la actividad humana sobre el sistema Tierra, Madrid: CSIC, 2006.

${ }^{34}$ MOTAVALLI, Jim, "Prólogo" a Motavalli, Jim (Comp.), El cambio climático. Crónicas desde las zonas de riesgo del planeta, Barcelona: Paidós, 2005, pp. 9-16.

35 WORKING GROUP I CONTRIBUTION TO THE IPCC FIFTH ASSESSMENT REPORT, Climate Change 2013: The Physical Science Basis Summary for Policymakers, Stockholm, Sweden, 27 September 2013.

${ }^{36}$ BURROUGHS, William J., Climate Change. A Multidisciplinary Approach, 2nd Edition, Cambridge: Cambridge University Press, 2007.

${ }^{37}$ SMITH, Lauren C., El mundo en 2050. Las cuatro fuerzas que determinarán el futuro de la civilización, Barcelona: Debate, 2011.
} 
of being limited to $2^{\circ}$ Celsius increased to $4^{\circ}$ Celsius. Heat waves, flooding in coastal cities, worsening water shortages, growing food production risks, increased tropical hurricane intensity and unprecedented loss of biodiversity make up the bleak picture that will likely emerge from this increase in temperature ${ }^{38}$.

It is unnecessary to resort to catastrophic projections to realize that the repercussions of climate destabilization are already perceptible worldwide, as well as their translation into social and economic changes, which are forcing people to move away from their homes, either temporarily or permanently. As highlighted by the aforementioned IPCC in its first report in 1990, human migration movements could be the greatest individual impact of climate change, since millions of people may be displaced ${ }^{39}$.

It should be noted that the causal relationship between climate change and population displacement is an area of controversial debate, in which natural and social scientists label each other as "maximalists" and "minimalists" ${ }^{40}$. However, this debate tends to depolarize, since both sectors coincide in recognizing that, broadly influenced by social, economic and political forces that determine the way in which societies interact with their environments, the relationship between climate change and (forced) migration is not linear but rather complex and "multicausal"41. In fact, as Margareta Wahlström argued, «it is not necessarily the temperature increase itself that poses the largest challenge in terms of human mobility, but the associated changes in, and combined effects of, precipitation patterns (drought and flooding), storms and sea level rise; loss of biodiversity, and ecosystem services; and resulting health risk, food and livelihood insecurity» ${ }^{42}$.

It is evident that the study of this reality still demands exhaustive and consistent empirical research, resulting from the use of more coherent and, where possible, unified

\footnotetext{
${ }^{38}$ POTSDAM INSTITUTE FOR CLIMATE IMPACT RESEARCH AND CLIMATE ANALYTICS, Turn Down the Heat: Why $a 4^{\circ} \mathrm{C}$ Warmer World Must Be Avoided, Washington D.C.: The World Bank, 2012.

${ }^{39}$ IPCC, First Assessment Report, Cambridge: Cambridge University Press, 1990.

40 LACZCO, Franc / AGHAZARM, Christine (eds.), Migration, Environment and Climate Change: Assessing the Evidence, Geneva, 2009.

${ }^{41}$ FRITZ, Carolina, Climate Change and Migration: Sorting through Complex Issues without the Hype, Washington: Migration Policy Institute, 2010 [online] (retrieved 9.12.2017).

42 Nansen Conference on Climate Change and Displacement in the 21st Century, Oslo, 6-7 June 2011 [online] (retrieved 7.12.2017).
} 
methodologies ${ }^{43}$. It should also include the examination of such important issues as the plurality of factors that shape migration dynamics, the social determinants of people's vulnerability to climate change, and the diversity of migratory patterns associated with climate change.

Meanwhile, at their current evolutionary stage, the discussions about the causal nexus climate-displacement are marked by two main and complementary arguments. The first deals with the weight of environmental and climatic factors in migration and its connection with other agents of diverse natures. It is argued that understanding the role of the environment in migration dynamics may lead not only to the analysis of how and why people are vulnerable to climate change impacts, but also to examining the different strategies they develop to cope with or adapt to environmental adversity. In this sense, migration is considered one of many possible adaptation strategies. The second argument focuses on the political context in which migration flows occur, as well as on the treatment people displaced due to environmental factors should receive. Stemming from here, it discusses the protection deserved by people in situations of vulnerability to climate change, as well as the responsibilities of States and the international community in ensuring such protection. Without prejudice to the complementarity previously recognized between these two points of view, in coherence with its central concern this paper focuses more on the second.

In short, the need for further scientific and systematic research to deepen the understanding on this subject is undeniable ${ }^{44}$. However, this does not prevent us from realizing that, although it is impossible at present to determine their magnitude precisely, displacements due to the impacts of climate change are already a fact and may become exacerbated in the foreseeable future ${ }^{45}$. Most of these movements take place within countries, although the dimension of potential external displacements should not be

\footnotetext{
${ }^{43}$ STAL, Marc / WARNER, Koko, The Way Forward. Researching the Environment and Migration Nexus. Research Brief based on the Outcomes of the 2nd Expert Workshop on Climate Change, Environment, and Migration 23 - 24 July 2009, Munich, Germany. Bonn: UNU-EHS, 2009, p. 7.

${ }^{44}$ RENAUD, Fabrice / BOGARDI, Janos J. / DUN, Olivia / WARNER, Koko, Control, Adapt or Flee. How to Face Environmental Migration?, cit., p. 33.

${ }^{45}$ IFRC, Cambio climático y movilidad humana: punto de vista humanitario, 22 de abril 2009 [online] (retrieved 9.12.2017).
} 
underestimated $^{46}$. This highlights the already mentioned trend of climate change becoming the most important factor generating forced displacement.

In view of all the above, we will now review the conceptual framework that is being developed regarding the victims of these displacements. The framework is, in short, an effort to identify, define and/or categorize as clearly as possible their situation and/or special needs in order to treat them properly in the international legal-political sphere.

\section{In search of an appropriate conceptual framework}

The debates outlined above on the complex links between climate change and human mobility are closely linked to the persistent lack of consensus on the concepts and terminology to be used to refer to people who migrate due to environmental factors. Expressions such as "environmental migrants", "climate refugees", "environmental refugees", "ecological refugees", "environmental migrants", "environmentally displaced persons", inter alia, make up the variety of concepts and terms in use, scattered in the existing literature, and thus adding some confusion to the subject rather than clarifying it. It is evident that climate change is challenging language, legislation, and pre-established institutions in their approach to human displacement ${ }^{47}$. Indeed, the environmental displacement taking place in the context of climate change is clearly a "new reality" that demands an original approach and creative and imaginative responses in both the conceptual, normative and political-institutional realms.

In the process of constructing the conceptual and terminological framework that we are dealing with, a number of authors have already placed greater or lesser emphasis on several related aspects, including: the (in)adequacy of refugee, migrant or displaced terms; the specific causality of the displacement; crossing or not of state borders; the sudden or progressive nature of the environmental disorder; its natural or human origin; and the voluntary or forced, temporary or permanent character of the displacement. However, attempts to conceptualize people displaced by environmental factors so far exclude or contradict some or several of these aspects. In addition, directly or indirectly, authors try

\footnotetext{
46 KÄLIN, Walter / SCHREPFER, Nina, Protecting People Crossing Borders in the Context of Climate Change. Normative Gaps and Possible Approaches, Geneva: UNHCR, Division of International Protection, 2012.

${ }^{47}$ COHEN, Roberta / BRADLEY, Megan, "Disasters and Displacement: Gaps in Protection”, International Humanitarian Legal Studies, Vol. 1 (2010), p. 3.
} 
to position themselves in favor or against the need to articulate mechanisms of international protection for these people ${ }^{48}$. However, what is most important in this sense, authors seem to agree that «it makes a big difference whether people are perceived as refugees, other types of forced migrants or voluntary migrants ${ }^{49}$. This denotes the strong political component - beyond the scientific and academic - of this debate.

\section{a) "Environmental refugees"}

Although it is not recognized in International Law, the term "environmental refugee" has become the most popular of all the aforementioned. This is due largely to its "strength" in attracting the international community's attention to issues related to the protection of human rights of people displaced for environmental reasons ${ }^{50}$. Introduced in the 1970s by Lester Brown $^{51}$, its use was generalized by Essam El-Hinnawi who, in 1985, elaborated a policy document for the United Nations Environment Program entitled "Environmental Refugees". Therein he provided the first formal definition of "environmental refugees", understood as people «who have been forced to leave their traditional habitat, temporarily or permanently, because of a marked environmental disruption (natural and/or triggered by people) that jeopardized their existence and/or seriously affected the quality of their life» ${ }^{52}$.

The institutional linkage of this author has given rise to the belief that this definition perhaps lies more in the humanitarian mission of his organization than in the use of analytical criteria ${ }^{53}$. However, given its pioneering character, the recognition of the potential heterogeneity of environmental displacement as well as the different types of people displaced by environmental factors, this definition has become the obligatory

\footnotetext{
48 NASER, Mostafa M., "Climate Change-Induced Displacement: Definitional Issues and Concerns", Chicago-Kent Journal of Environmental and Energy Law, Vol. 2, Issue 1 (2011), pp. 1-52.

49 CASTLES, Stephen, Environmental change and forced migration: making sense of the debate, New Issues in Refugee Research, Working Paper 70, Geneva: UNHCR, 2002, p. 9.

${ }^{50}$ BOANO, Camillo / ZETTER, Roger / MORRIS, Tim, Environmentally displaced people Understanding the linkages between environmental change, livelihoods and forced migration, Refugee Studies Centre's Forced Migration Policy Briefings, University of Oxford, 2008, p. 1.

${ }^{51}$ MORRISSEY, James, Environmental Change and Forced Migration. A State of the Art Review, Refugee Study Center's Background Paper, University of Oxford, 2009, p. 3.

52 EL-HINNAWI, Essam, Environmental Refugees, Nairobi, Kenya: United Nations Environmental Programme, 1985, p. 4.

${ }^{53}$ BATES, Diane C., "Environmental Refugees? Classifying Human Migrations Caused by Environmental Change", Population and Environment, Vol.23, Issue 5 (2002), p. 466.
} 
starting point for work on this subject, which has already generated a vast amount of literature and long debates. Names such as Jacobson ${ }^{54}$, Myers, Kent ${ }^{55}$ and Bates are among those who have made a significant contribution to popularizing the use of the term "environmental refugees" and improving its conceptualization. Their contributions have a common denominator: they do not distinguish whether displaced persons have crossed an internationally recognized state border or not ${ }^{56}$.

In the meantime, we must point out that, from the research perspective, the juxtaposition of the terms "environment" or "climate" with "migrants" or "refugees" has been criticized for suggesting a "monocausal" connection between environmental factors and human mobility, thereby denying the multiplicity of causes leading to environmental displacements ${ }^{57}$. Obviously, this critical assessment conditions most of terminology and concepts adopted so far.

It should be stressed that applying the term "refugee" to those displaced by environmental factors caused by climate change still raises a number of persistent objections and controversies. Stephen Castles ${ }^{58}$, for example, considers the term "environmental refugee" to be simplistic, unilateral and misleading, since it involves an exclusive cause, which is seldom true in practice. Thomas Homer-Dixon also opposes the use of this term as "misleading"59. More bluntly, Richard Black denies the existence of "environmental refugees" or "climate refugees", as he considers them "a myth"60.

\footnotetext{
54 JACOBSON, Jodi L., Environmental Refugees: A yardstick of habitability. Washington: Worldwatch Institute, 1988, pp. 37-38.

${ }^{55}$ MYERS, Norman / KENT, Jennifer., Environmental Exodus: An Emergent Crisis in the Global Arena, Washington DC: The Climate Institute, 1995, definieron a los "refugiados ambientales" como personas: «who can no longer gain a secure livelihood in their erstwhile homelands because of drought, soil erosion, desertification, and other environmental problems. In their desperation, they feel they have no alternative but to seek sanctuary elsewhere, however hazardous the attempt. Not all of them have fled their countries; many are internally displaced. But all have abandoned their homelands on a semi-permanent if not permanent basis, having little hope of a foreseeable return» (pp. 18-19).

${ }^{56}$ RENAUD, Fabrice / BOGARDI, Janos J. / DUN, Olivia / WARNER, Koko, Control, Adapt or Flee. How to Face Environmental Migration?, cit., p. 13.

${ }^{57}$ PIGUET, Étienne / PÉCOUD, Antoine / GUCHTENEIRE, Paul de (eds.), Migration and Climate Change, Paris/Cambridge: UNESCO/Cambridge University Press, 2011, pp. 17-20.

${ }^{58}$ CASTLES, Stephen, Environmental change and forced migration... op.cit., p. 5.

${ }^{59}$ HOMER-DIXON, Thomas, Environmental Scarcity and Global Security, Headline Series, N³00, New York: Foreign Policy Association, 1993, pp. 40-41).

${ }^{60}$ BLACK, Richard, Environmental Refugees: Myth or Reality? New Issues in Refugee Research Working Paper No. 34, Geneva: UNHCR, 2001.
} 
From the political-legal point of view, the terms "environmental refugee" or "climate refugee" are rejected as they are considered an extrapolation of the term refugee commonly used to designate a person fleeing violence and persecution. The legal definition of a "refugee" is outlined in the 1951 Convention and its 1967 Protocol on the Status of Refugees, and does not include environmental factors. It is further argued that the use of the term "refugee" in the context of climate change could dilute the refugee figure, which would cease to be a specific legal category and become a broader and indefinite category. The $\mathrm{UNHCR}^{61}$ itself has sought to settle the debate by stating that these terms have no basis in international refugee law, and that most of those commonly described as "climate refugees" or "refugees from environmental disasters" have not crossed an international border. Furthermore, it states that the use of this terminology could undermine the international legal regime for the protection of refugees and create confusion by suggesting a link between the impact of climate change, environmental degradation, migration and persecution, the latter being the main reason for a refugee to flee his or her country of origin and seek international protection.

Based on the convenience and usefulness of the terminology, several analysts ${ }^{62}$ still consider that even though it is not legally correct, this term ("environmental refugee") proves to be the most convincing as it puts the human face on the consequences of climate change, evokes a sense of global responsibility towards them and also a sense of urgency to deal with imminent or ongoing disasters. Certainly, this reasoning makes an interesting point in the debate. However, the UNHCR's "positioning of authority" makes the use of this terminology nonviable and determines the need to find alternatives.

\section{b) Alternative terminology}

In 2007, the International Organization for Migrations (IOM) proposed the use of the term "environmental migrants" to refer to "persons or groups of persons who, for compelling reasons of sudden or progressive changes in the environment that adversely affect their lives or living conditions, are obliged to leave their habitual homes, or choose to do so,

\footnotetext{
61 ACNUR, Cambio climático, desastres naturales y desplazamiento humano: la perspectiva del ACNUR, 2009, pp. 8-9.

${ }^{62}$ Like STAVROPOULOU, Maria, “Alterações climáticas: desastres naturais e deslocações forçadas”, en: Refugiados e deslocados ambientais: o lado humano das alterações climáticas”. Actas do IX Congresso Internacional do Conselho Português para os Refugiados, Lisboa: CPR, p. 38.
} 
either temporarily or permanently, and who move either within their country or abroad". Despite the effort of this organization to demonstrate the opposite, for many this definition is equally unsatisfactory, since, according to its detractors, it has the same problem mentioned above: "monocausality" to the detriment of the "multi-causal" character of reality. In contrast, the expression "population movements induced by environmental factors" has been considered; however, this phrase, in addition to being vague and diffuse, is not attractive to the general public ${ }^{63}$.

One of the most rigorous and extensive studies on the connection between climate change and population movements - the EACH-FOR Project ${ }^{64}$ - uses the term "displaced for environmental reasons", which is perhaps the most comprehensive, as it covers "environmental migrants", "environmentally displaced persons" and "people displaced for development reasons". However, blurring the boundaries between these three subcategories prevents this term from being satisfactory.

Therefore, it is clear that there is persistent terminological dissent and so far no valid or consistent definition, which has led to an institutional and normative vacuum. There is no doubt that language is decisive, since it frames the problem and defines the response, rights and responsibilities. In this sense, a precise definition would be a crucial step towards the design and development of the desired institutional and legal framework and active policies for the protection and assistance given to displaced persons (both externally and internally), likely victims of environmental adversities either natural disasters or related to climate change. In any case, and as Walter Kälin warned ${ }^{65}$, «we should not be distracted by semantic discussions with little practical meaning about whether to call affected persons "climate change refugees", "environmental migrants" or something else. Instead, what is needed is a thorough analysis of the different contexts and forms natural disaster induced displacement can take».

It is a question of the participants in the debate sharing a fundamental understanding. Therefore, the variety of terms should not prevent the development of a coherent common

\footnotetext{
${ }^{63}$ PIGUET, Étienne / PÉCOUD, Antoine / GUCHTENEIRE, Paul de (eds.), Migration and Climate Change, op.cit., p. 181.

${ }^{64}$ RENAUD, Fabrice / BOGARDI, Janos J. / DUN, Olivia / WARNER, Koko, Control, Adapt or Flee. How to Face Environmental Migration?, op.cit.

${ }^{65}$ KÄLIN, Walter, The Climate Change - Displacement Nexus, Brookings, 2008 [online] (retrieved 7.12.2017).
} 
approach to what is really at stake ${ }^{66}$.

With all these arguments in mind, and without the slightest pretense of adding confusion, here we opt for the term "environmentally displaced person", which is intended to designate all persons or groups of persons who have been forced or obliged to escape or flee their home or place of habitual residence for an indeterminate period of time as a result of or to avoid the effects of natural or man-made disasters, including those caused by climate change, whether or not they have crossed an internationally recognized State border. This general definition aims to promote an overall view of the environmental displacement problem, giving due weight to environmental factors motivated by climate change, but without neglecting the complex linkages and interactions between these factors, socio-political factors and human mobility factors. From this conceptual overview, we will try to approach the magnitude and geography of "environmentally displaced people".

\section{Magnitude and amplitude of environmental displacement}

Linked to the precocity and fluctuations of the above-mentioned epistemological status of human displacement in the context of climate change, the figures of environmentally displaced persons that have been recently handled vary greatly depending on the definitions and environmental factors, the hypotheses proposed as well as the methodologies used ${ }^{67}$. It is clear that the growing awareness of the connection between climate change and human mobility still lacks sufficient empirical research that could lead to conclusive results ${ }^{68}$.

Consequently, the quantification of "environmentally displaced persons" remains a territory of unlikely consensus among the different parties in the debate, specifically between "skeptics" and "alarmists". Lonergan, for example, suggests that existing estimates and projections rely almost exclusively on "anecdotal evidence and intuitive

\footnotetext{
${ }^{66}$ PIGUET, Étienne / PÉCOUD, Antoine / GUCHTENEIRE, Paul de (eds.), Migration and Climate Change, op.cit., p. 184.

${ }^{67}$ AFIFI, Tamer / WARNER, Koko, The Impact of Environmental Degradation on Migration Flows across Countries, UNU-EHS Working Paper 5, 2008, p. 4.

${ }^{68}$ KNIVETON, Dominic / SCHMIDT-VERKERK, Kerstin / SMITH, Christopher / BLACK, Richard, Climate Change and Migration: Improving Methodologies to Estimate Flows, Geneva: IOM - Migration Research Series Paper No. 33, 2008, p. 5.
} 
judgments"69. Nevertheless, he warns about the importance of not underestimating the role that environmental alterations and the scarcity of resources can play in population displacements. In turn, the IPCC itself, for a number of reasons, considers most projections as "mere conjectures". However, in its aforementioned Fifth Report (2014), this institution provides overwhelming data on the physical and environmental consequences of climate change that would lead to the displacement of millions of people.

The need for specific research and objective assessments is therefore indisputable, in order to gain a better understanding of the problem and be able to make credible predictions and valid estimates, surpassing mere conjectures and "academic approximations". Meanwhile, there is an increasing number of experts who do not hesitate to place climate change among the main causes of forced migration, noting the existence of millions of people already displaced and millions of others who may be displaced as climate change impacts become more acute ${ }^{70}$.

Norman Mayer predicted that by 2050, up to 200 million people could be displaced due to environmental and climate reasons. It is worth bearing in mind that by then, out of a world population estimated at 9 billion people, one in 45 people might be displaced for these reasons. This makes population displacements "one of the most serious challenges" and "one of the main political problems" to be faced over the 21 st century ${ }^{71}$.

Joining the "numbers game", the United Nations Environment Program (UNEP) estimates that by 2060, in Africa alone there could be some 50 million environmentally displaced persons $^{72}$. This reinforces forecasts that the impact and consequences of environmental degradation related to climate change could be exceptionally severe in this region of the world. We will come back to this later.

The most "apocalyptic" of the above-mentioned estimates so far belongs to Christian Aid. In 2007 , this institution predicted that by 2050, around 1 billion people could be permanently displaced. Among them, 250 million due to climate change related phenomena such as droughts, floods and hurricanes, and 645 million as a result of dam

69 LONERGAN, Steve, "The Role of Environmental Degradation in Population Displacement", Environmental Change and Security Project Report, Issue 4 (1998), pp. 5-15.

${ }^{70}$ STEINER, Achim, "Prólogo" a la $R M F, \mathrm{n}^{\circ} 31$ (2008), p. 4.

${ }^{71}$ KÄLIN, Walter, "The Climate Change - Displacement Nexus, op.cit.; MORTON, Andrew / BONCOUR, Philippe / LACZKO, Frank, "Seguridad humana y desafíos Políticos", RMF, n³1 (2008), pp. 5-7.

72 BROWN, Oli, “El baile de las cifras", $R M F, \mathrm{n}^{\circ} 31$ (2008), pp. 8-9. 
construction and other large-scale development projects.

It is therefore not surprising that from these figures, some circles have begun to talk about what they call the largest mass global migration in the history of mankind ${ }^{73}$. As a result, "demographic catastrophes" and large-scale international migration flows have been predicted to "damage the nature of destination regions and countries and thereby exacerbate the risk of conflict"74. There is no need to demonstrate how dangerous this approach is since it promotes xenophobia and social tensions by diverting attention from the protection and assistance that refugees and internally displaced persons need.

In a meritorious effort to overcome the "alarmism", in 2009 OCHA and IDMC unveiled a pioneering study that assessed the worldwide existence of 36 million displaced persons in 2008 alone, as a consequence of natural disasters. This number amounted to more than 42 million in 2010, dropping to almost 15 million in 2011, but reaching 32.4 million at the end of 2012. Of these data it is estimated that the amount of people displaced due to environmental reasons linked to climate change was around 20 million in 2008, over 38 million in 2010, almost 14 million in 2011 and 98\% of the given figure for 2012 (32.4 million) $)^{75}$. In the same period, there were approximately 4.6 million (2008), 2.9 million (2010), and 3.5 million (2011) people displaced due to violence. This highlights the trend that environmental phenomena related to climate change are becoming the main factor causing population displacement around the world.

In fact, we are witnessing the progressive affirmation of climate change, which is becoming the dominant force inducing human displacement, since it acts as an amplifying factor on conflicts and other elements of socio-economic vulnerability. In providing the global scale of displacement caused by disasters, many of them related to climate change, the $\mathrm{IDMC}^{76}$ points out that environmental disasters displace three times more people than conflicts. In fact, as illustrated below (Figure 2),

"Since 2008, an average of 26.4 million people per year have been displaced from their homes by disasters brought on by natural hazards. This is the

\footnotetext{
${ }^{73}$ LECKIE, Scott, ”Implicaciones sobre los derechos humanos”, $R M F, \mathrm{n}^{\circ} 31$ (2008), pp. 18-19.

${ }^{74}$ RSH-OIM, El cambio climático, la degradación del medio ambiente y la migración: qué hacer ante las circunstancias de vulnerabilidad de la población y cómo aprovechar las oportunidades de solventar el problema. Informe de la Conferencia, Ginebra, 2008, p. 8.

${ }^{75}$ IDMC, Global estimates 2012. People displaced by disasters, Geneva: IDMC, May 2013.

76 IDMC, GRID 2017, cit.
} 
equivalent to one person being displaced every second. The number and scale of huge disasters creates significant fluctuation from year to year in the total number of people displaced, while the trend over decades is on the rise".

In its key findings, this same institution indicates that "by the end of 2016 there were 40.3 million people internally displaced by conflict and violence across the world. An unknown number of people remain displaced as a result of disasters that occurred in and prior to 2016".

It should be noted that, although the number of people displaced by disasters is unknown exactly, the IDMC asserts that, adding to the already existing high number of internally displaced people by conflict and disaster, in 2016 alone a total of 31.1 million new displacements were recorded in 125 countries and territories, which is roughly the equivalent of one person forced to flee every second. Of this total number, 24.2 million of the displaced people fled due to disasters, while 6.9 were motivated by conflict and violence.

Figure 2: Total annual new displacements since 2008

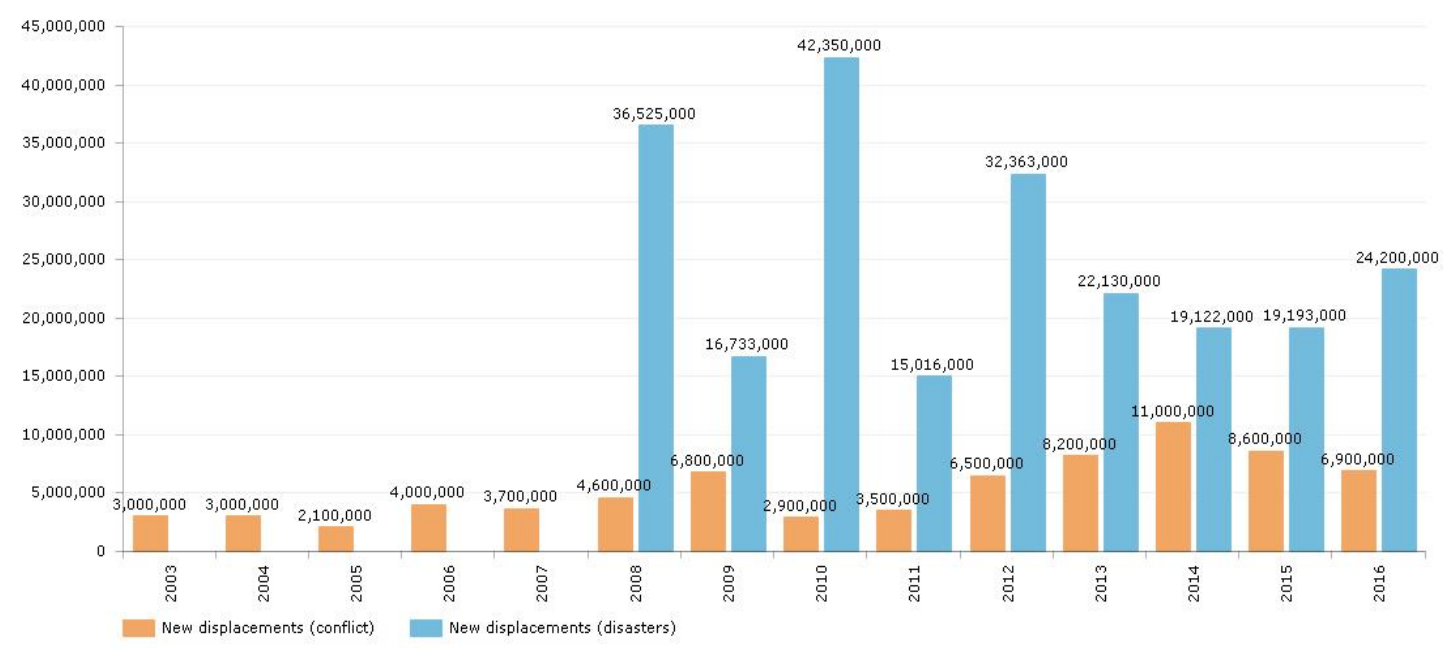

Source: IDMC, GRID 2017.

Regarding the direction, there is a broad consensus on the largely internal nature of displacement in the context of climate change; however, it should be emphasized that the number of environmentally displaced persons crossing state borders, and thus this issue, should not be underestimated.

From all of the above, it is necessary to come to the conclusion that the environmental 
displacement occurring in the context of climate change constitutes a "new reality". This overflows and poses enormous challenges to the legal order and international policies and relations, thereby demanding that new and imaginative answers be adopted. In this regard, and in order to analyze the extent to which international law is and should be an essential instrument for the management of environmental displacement as a social problem, the following two sections will review both the international recognition of environmental displacement and the evolution of State obligations towards victims.

\section{International recognition of environmentally displaced people}

Both the UNFCCC ${ }^{77}$ and the Kyoto Protocol to the United Nations Framework Convention on Climate Change ${ }^{78}$ make no explicit reference whatsoever to displacement induced by climate change. Thanks to the decisive action of important sectors of the humanitarian community, international awareness on the issue has grown, and so has the need for a tighter integration of humanitarian and human rights approaches into international negotiation processes on climate change.

While inviting all State parties to enhance their efforts of adaptation by implementing inter alia "measures to enhance understanding, coordination and cooperation with regard to climate change induced displacement, migration and planned relocation, where appropriate, at the national, regional and international levels", Article $14 \mathrm{f}$ ) of the Cancun Agreements (Decision 1.CP/16) represents a turning point in the official recognition by state communities both of population displacement due to the impacts of climate change and the need to adequately address this reality at all levels: local, national, regional and international. In fact, it should be stated that this article was the first time that the environmental displacement issue was included in the international agenda.

However, it should be highlighted that this remarkable step had no continuity in successive climate change conferences. This is said without ignoring the Decision on Loss and Damage adopted in Doha in 2012 (Decision 3.CP/18 paragraph 7 (a) (vi)), in which paragraph 50 refers to "integrated approaches to avert, minimize and address displacement related to the adverse impacts of climate change", or the Warsaw International Mechanism

\footnotetext{
77 Adopted in New York on $9^{\text {th }}$ May 1992, it came into force on $21^{\text {st }}$ March 1994. UNTS, Vol. 1771, p. 107.

78 Adopted in Kyoto on $11^{\text {th }}$ December 1997, it came into force on $16^{\text {th }}$ February 2005. UNTS, Vol. 2303, p. 148.
} 
for Loss and Damage, established by COP 19 to address loss and damage associated with impacts of climate change, including extreme events and slow onset events, in developing countries that are particularly vulnerable to the adverse effects of climate change.

Adopted by COP $21^{79}$, the Paris Agreement, the first-ever universal, legally-binding global climate deal, which sets out a global action plan to limit global warming to well below $2^{\circ} \mathrm{C}$, is by many considered as an unprecedented breakthrough for action on migration and climate change or, mutatis mutandis, a stepping stone for the protection of environmentally displaced people. However, it can be conversely argued that the issue of human mobility taking place in the context of climate change is widely underrepresented in the Paris Agreement. In fact, the only mention of migrants in this treaty can be found in its preamble, which reads as follows:

"Acknowledging that climate change is a common concern of humankind, Parties should, when taking action to address climate change, respect, promote and consider their respective obligations on human rights, the right to health, the rights of indigenous peoples, local communities, migrants, children, persons with disabilities and people in vulnerable situations and the right to development, as well as gender equality, empowerment of women and intergenerational equity" (emphasis added).

Therefore, even in the aftermath of the Paris Agreement, it makes complete sense to consider that negotiations under the UNFCCC should continue to be a factor in the progress on the issue of human mobility in relation to climate change.

At any rate, once the reality of environmental displacement has been recognized, the correct approach under International Law requires, among other tasks, identifying its forced or voluntary character; classifying those affected as migrants, internally displaced persons, refugees or stateless persons; as well as analyzing the existence or not of an international normative and operational framework for responding adequately to this "multicausal" and "new reality". It is worth, at this point, recalling the distinction proposed by Kälin ${ }^{80}$ among five specific scenarios that trigger human displacement and migration: i) the increase in hydro-meteorological disasters (flooding, hurricanes/typhoons /cyclones,

\footnotetext{
${ }^{79}$ FCCC/CP/2015/L.9.

${ }^{80}$ KÄLIN, Walter, The Climate Change - Displacement Nexus, op.cit..
} 
mudslides, etc.); ii) designated areas as high-risk zones too dangerous for human habitation; iii) environmental degradation and slow onset disasters (e.g. reduced water availability, desertification, recurrent flooding, salination of costal zones, etc.); iv) "sinking" small island states caused by rising sea level; and v) decrease in essential resources (water; food production) due to climate change, which can trigger armed conflict and violence. Needless to say, these diverse scenarios shape different subcategories of displaced persons or migrants, posing considerable challenges, at the very least from legal and humanitarian perspectives, and at domestic, regional and international levels.

\section{International obligations of States under the legal regime on climate change}

At its current evolutionary stage, International Law imposes three kinds of general obligations for States in the context of climate change: mitigation, adaptation and protection.

Focusing on causes of climate change, mitigation implies the commitment of State parties to the UNFCCC and its Kyoto Protocol as well as to the Paris Agreement in order to reduce and limit global warming to well below $2^{\circ} \mathrm{C}$, thereby curbing the ongoing climate change and its disastrous consequences. Considering that, due to the inertia of the climatic system, it is already impossible to avoid some of its effects ${ }^{81}$, States commit to undertaking adaptation measures, thus reducing the risk of disasters and structural weaknesses whilst enhancing the resilience of people and communities, especially in developing countries. The third obligation seeks to address the impacts of climate change by protecting the human rights of the affected people, including those environmentally displaced.

It should be noted that international negotiations under the UNFCCC on the fight against climate change still remain focused on mitigation and adaptation; the protection of people has not yet been taken into account to a sufficient degree. Even so, we must acknowledge that, although climate change has been recognized as a cause of human mobility that can increase risks and vulnerability, regretfully human mobility seems far from being accepted and supported as an adaptation strategy to climate change, as a mechanism that can

${ }^{81}$ LABANDEIRA, Xavier / LINARES, Pedro, «El Acuerdo de París sobre cambio climático», ICADE (2016), núm. 97, p. 12. 
increase the resilience of the people affected by climate change's negative impacts. As emphasized by António Guterres ${ }^{82}$, "although there is a growing awareness of the perils of climate change, its likely impact on human displacement and mobility has received too little attention".

\section{Protecting environmentally displaced people: a pending issue}

It has been stressed that the task of assessing the protection of people in the context of the global and multi-level response to climate change should be based on the foundations of humanity, dignity, human rights, solidarity and international cooperation. Based on these principles, States have the primary responsibility to protect their populations, giving particular attention to the special needs of those most vulnerable and affected by environmental disasters, including displaced people, host communities and those at risk of displacement. To this end, it is essential that legislation, policies and institutions are developed, and investment is made in adequate resources.

In the wake of discussions and the five scenarios of displacement outlined above, it is worth noting that States may face difficulties on how to deal with the these different subcategories of environmentally displaced people and on how to determine the type of protection to be granted. To begin with, there is neither a mandatory definition of environmentally displaced people nor specific rules that could help to frame and regulate the protection that they need and deserve; hence the existence of a legal and institutional vacuum in this regard. This is despite the fact that a thorough examination of the existing rules - particularly in Refugee Law, Humanitarian Law, Human Rights Law, Environmental Law and even the Guiding Principles on Internal Displacement - leads to the conclusion that, for their protection and assistance, some environmentally displaced people might be sufficiently covered by the current legal and institutional framework.

It is worth remembering and insisting that the five scenarios mentioned above are considered useful for, among other things, categorizing those who move as migrants, internally displaced persons, refugees, stateless persons or several of these assumptions at the same time. Certainly, this is a risky and debatable task that requires the development of specific analysis criteria. Notwithstanding, it seems to be opportune to look at the

${ }^{82}$ GUTERRES, António, "Millions Aprooted. Saving Refugees and Displaceds", Foreign Affairs, 2008 [online] (retrieved 9.12.2017). 
direction of displacement, which allows us to address two subcategories of environmentally displaced people, resulting from internal and external migratory movement.

\section{a) Internal environmentally displaced people}

We must emphasize once again both the predominantly internal nature of the environmental displacement crisis and the primary responsibility of States for the protection of victims. It should not be forgotten that, most of the time, the displaced people are citizens of countries whose governments are unable or unwilling to provide them with assistance and protection. This situation itself should trigger international protection. In addition, acceptance of climate change as a root cause of displacement implies, therefore, the international community's assumption of common and shared responsibility to protect and assist victims. However, the inclusion of this protection in the emerging principle of $\mathrm{R} 2 \mathrm{P}$ has proven to be a highly controversial issue that has so far attracted more detractors than supporters.

It is widely believed that existing human rights norms and the Guiding Principles on Internal Displacement make up the normative framework of reference to ensure international protection for the vast majority of environmentally displaced people, who are, ultimately, internally displaced people. While the Guiding Principles do not explicitly include climate change among the causes of internal displacement, they do so implicitly in providing a non-exhaustive list of causes and factors for such displacement. In particular, Guiding Principles expressly recognize natural and man-made disasters as potential root causes of displacement, regardless of their linkages to climate change patterns.

However, Guiding Principles have certain shortcomings that may give rise to the lack of protection of internally displaced persons. It should be recalled that, in addition to their non-binding nature, these Principles have definition problems, more descriptive than legal; they do not adequately cover environmental alterations in their complexity and breadth; they seem to focus more on displacements resulting from sudden environmental phenomena, leaving aside those that occur as a result of slow and progressive environmental disasters. Moreover, their transformation from soft law principles into national normative standards and policies of protection has proven insufficient and far from exhaustive. All of this is compounded by the enormous challenges of their 
implementation, shortcomings in institutional arrangements, and the unlikely emergence of any realistic alternative framework. It is therefore necessary to conclude that the protection of the human rights of internal environmentally displaced persons is far from being sufficiently assured.

On the other hand, those people who, presumably, make the decision (without being forced) to leave their homes and places of habitual residence due to the effects of climate change, such as environmental degradation that adversely affects food production, are often included in internal migration (voluntary). This is usually taken for granted without considering or promoting migration as a mechanism of adaptation to climate change.

\section{b) External environmentally displaced people}

The lack of a specific and comprehensive legal framework for protection is even more blatant regarding the transboundary movement of people in the context of climate change. For external environmentally displaced persons who do not fit into any legally established status for "economic" or "forced" migrants across state borders, the human rights protection system, while still relevant in general terms, is nothing but a nominalist system $^{83}$.

It should also be recalled that, with very few exceptions - such as the fifth scenario of displacement, in which climate change can trigger disturbances, violence and armed conflicts; or scenarios 1 and 2 , in the event that national authorities "politicized" the assistance and, in a discriminatory attitude, refused to provide any kind of protection and assistance to certain people due to their race, religion, nationality, membership of a particular social group or political opinion - external environmentally displaced people do not fall within the scope of the international legal regime for refugees. This is so even in those regional areas - such as the African and Latin American regional areas - where significant extensions have been made to the Geneva definition of the term refugee. In fact, both the OAU Convention regulating specific aspects of refugee problems in Africa (Article 1.2) and the Cartagena Declaration on Refugees (in their third conclusion), include among the constitutive assumptions of refugee status those events that may seriously disturb public order. In this sense, both instruments could cover environmentally

${ }^{83}$ KÄLIN, Walter / SCHREPFER, Nina, Protecting People Crossing Borders..., op.cit., pp. 32-33. 
displaced people since the impact of disasters can become severe enough to violate public order. However, although it seems possible, this interpretation still finds no support in either the praxis or the opinio iuris of States in these two regions.

In any case, it is possible that certain aspects of the Refugee Law could be of great help in developing responses to population movements in the context of climate change. Following Jane McAdam ${ }^{84}$, we are looking in particular at its criterion of proof ("wellfounded fear"), the envisaged durable solutions, its rights-based protection framework and the status it creates, as well as institutional monitoring guaranteed by UNHCR. It should also be noted that, well understood and informed by principles of dignity, human rights and international cooperation, the institute of non-refoulement can provide the necessary foundation for the development of an adequate framework for the protection of those environmentally displaced people who manage to cross State borders. Clearly, currently all this is nothing more than good intentions or a mere aspiration of a still minority sector in a somewhat enclosed debate.

The lack of a legal, political and institutional framework to provide protection for environmentally displaced people still prevails in the international arena. However, the relevance of regional organizations in the fight against climate change has been recognized in the correlative international negotiations process, as clearly reflected in the aforementioned paragraph $14 \mathrm{f}$ ) of the Cancun Agreements. This gives us the opportunity to return to the Kampala Convention with the aim of evaluating how effective its implementation has been and should be in providing protection to environmentally IDPs in the African Union regional context.

\section{THE IMPLEMENTATION OF THE KAMPALA CONVENTION: ARE THE ENVIRONMENTAL IDPS BEING PROTECTED?}

Regretfully, the weakness of the pan-African organization with regard to the implementation of its own legal and political instruments is far from being new. For this reason, our starting point for assessing the effectiveness of the Kampala Convention is cautiously and justifiably pessimistic. This, however, instead of conditioning our gaze, provides us with preparedness for identifying, evaluating and celebrating possible good

\footnotetext{
${ }^{84}$ MCADAM, Jane, Climate Change, Forced Migration and International Law, Oxford: Oxford University Press, 2012, p. 51.
} 
practices that may exist in the region regarding the domestication and implementation of the said convention.

\section{Identifying good practices in domestication and implementation}

When it comes to identifying good practices in domestication and implementation, the first meeting of the Conference of State Parties to the Kampala Convention, held in Harare on $5^{\text {th }}$ April 2017, can be considered as a good starting point. Along with showing political will to fulfill State obligations towards IDPs, this landmark event itself tells much about the 27 State parties' strong commitment to making concrete progress in implementing the convention.

State parties seem to be aware of the fact that, although the adoption of the Kampala Convention is generally heralded a momentous achievement for the African Union, like other instruments, its effectiveness lies in its integral implementation as well as in the translation of its provisions to assure real protection and assistance to IDPs across the continent. In this sense, convened by the African Commission in accordance with Article 14 of the Kampala Convention, the aforementioned first meeting aimed to explore ways of strengthening cooperation and solidarity among State parties in dealing with the issue of internal displacement and mechanisms and ways of enhancing the domestication and implementation of the convention.

Certainly it is early to take a look back to see what progress has been made since the Kampala Convention was adopted (roughly eight years ago) and came into force (almost five years to date). Understandably, those who have attempted to do so and insisted on the need to turn theory into practice ${ }^{85}$ did not manage going beyond the evaluation of the ratification process. Indeed, ratification is the most basic criterion to be considered in carrying out the assessment that is intended here. As of August 2017, 40 of the 55 State Members of the African Union had signed the Kampala Convention, while 27 had ratified it, including the Sahrawi Arab Democratic Republic, which is not a State member of the United Nations ${ }^{86}$. Therefore, to date the ratification of the convention has been a successful process, so much so that it has become the fastest AU treaty to enter into force.

85 IDMC, The Kampala Convention One year on: Progress and prospects, Geneva, 2013; IDMC, The Kampala Convention two years on: time to turn theory into practice. Briefing Paper, Geneva, 2014.

86 See "List of Countries which have signed, ratified/acceded to the Kampala Convention" [online] (retrieved 9.12.2017). 
However, although it is important, ratification itself is nothing but a step forward towards making effective an instrument that has been conceived and aptly considered as a road map for action.

In order to facilitate the implementation of the Kampala Convention, the above referred first meeting of the Conference of State parties set the Harare plan of action (PoA) with priorities and activities to be adopted by the AU, State parties, Regional Economic Communities (RECs) and partners ${ }^{87}$. This collective effort towards the implementation of the convention and strengthening of mechanisms for cooperation, solidarity and coordination among member states, the AU and other stakeholders, has been rightly considered another fertile opportunity to pursue the aspirations of Agenda 2063: The Africa we want, which mainly lays emphasis on root causes, prevention and durable solutions to progressively eliminate forced population displacement across the continent ${ }^{88}$. Previous to the Harare PoA, in 2014 the African Union Commission on International Law launched a Draft AU Model Law for the Implementation of the Kampala Convention ${ }^{89}$, which is still under debate and intended to be used as a resource in the drafting process of national legislation to implement the Kampala Convention at the national level. It is expected that it will help encourage State parties to implement more quickly their obligation to "incorporate their obligations under this Convention into domestic law by enacting or amending relevant legislation on the protection of, and assistance to, internally displaced persons in conformity with their obligations under international law"90.

For their law and policy-making processes on internal displacement, State parties on the

87 "The PoA is structured around five objectives of the Kampala convention:

- $\quad$ Establish a framework for solidarity, cooperation and the promotion of durable solutions between state parties

- Establish a policy framework for the prevention, protection of and assistance to internally displaced persons (IDPs) at national level

- Promote and strengthen regional and national measures to prevent and eliminate the root causes of internal displacement and provide durable solutions

- $\quad$ Promote the obligations and responsibilities of State parties

- Identify specific obligations, roles and responsibilities of armed groups, non-state actors and other relevant actors including civil society organisations" ("1st meeting of the conference of State parties to the Kampala Convention” [online] [retrieved 9.12.2017]).

88 “Concept Note" <https://au.int/sites/default/files/newsevents/conceptnotes/32304-cn-concept_note__cosp_meeting_2017.pdf> (retrieved 9.12.2017).

${ }^{89}$ AUCIL/Legal/Doc.6 (IX).

${ }^{90}$ As foreseen under Article 3(2) of the Kampala Convention. 
Kampala Convention can likewise find support, among others, in the following instruments $^{91}$ : Domesticating the Kampala Convention: Law and Policy-making (2014); Capacity-building on law and policy-making on internal displacement (2016); National Instruments on Internal Displacement: A Guide to their Development (2013); and Regulatory Frameworks on Internal Displacement (2016).

As shown below (Figure 3), by May 2016 several African countries had developed or were developing domestic laws, policies and strategies on IDPs, using the Guiding Principles or the Kampala Convention as points of reference.

Figure 3: African countries that have adopted laws or policies on internal displacement

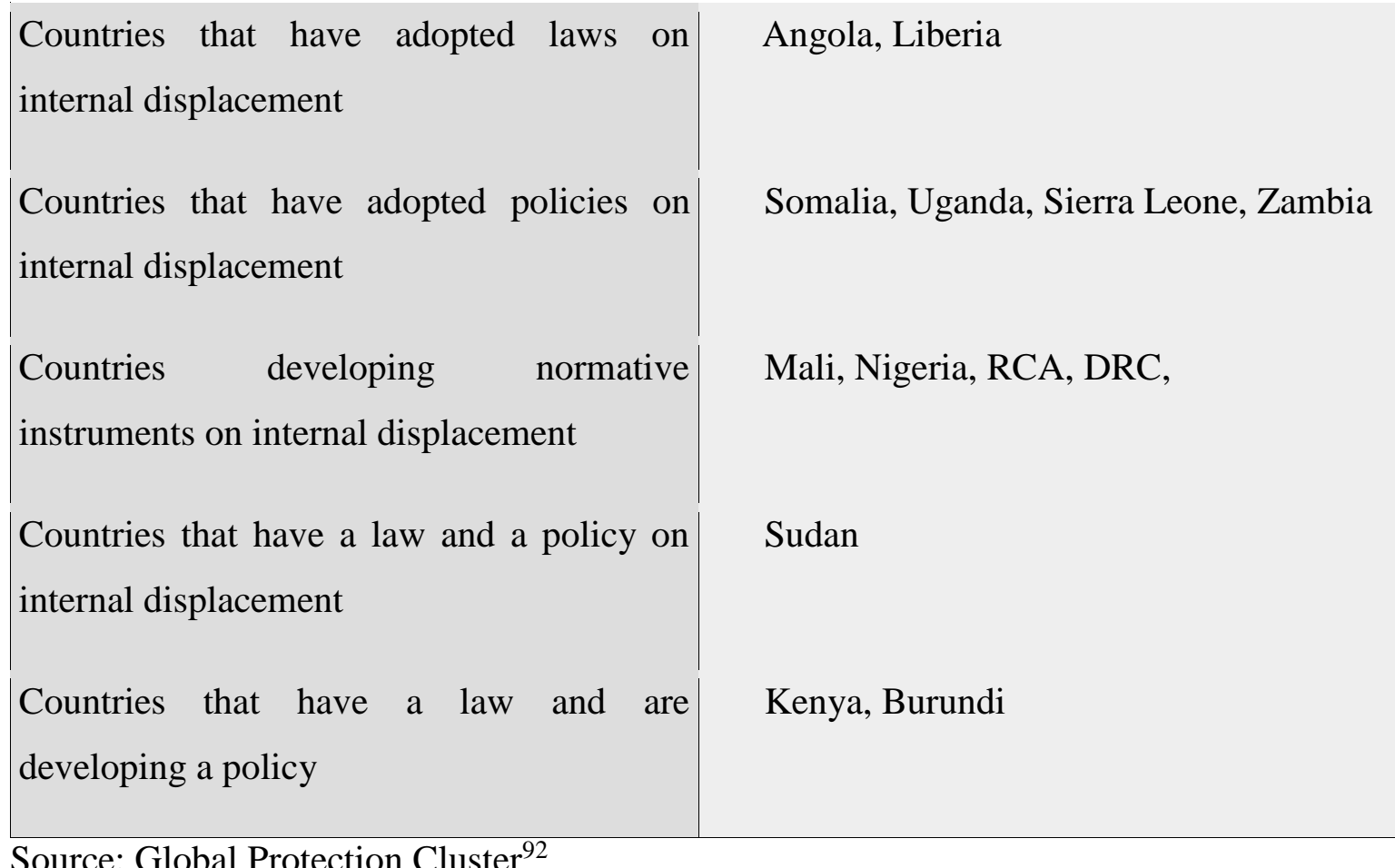

Keeping in mind the purpose of this paper, it is pertinent to wonder to what extent these national regulatory frameworks go beyond armed conflicts and provide protection to environmental IDPs, especially those provoked by slow-onset disasters.

\section{Are the environmental IDPs protected?}

It is interesting to note that not all the above-tabulated States are legally bound by the

\footnotetext{
${ }^{91}$ All of them available at http://internal-displacement.org/law-and-policy.

${ }^{92}$ GLOBAL PROTECTION CLUSTER, Regulatory Framework on Internal Displacement. Global, regional and national developments, May 2016 [online] (retrieved 7.12.2017).
} 
Kampala Convention. And the laws and policies developed by some of them, such as Angola (2000), Burundi (2001), Sierra Leone (2002), Uganda (2004), the Sudan (2009) and Kenya (2012), were adopted before their ratification of the convention. Another important aspect that needs to be highlighted is that the domestic frameworks adopted so far vary in scope, the guarantees of protection and assistance, and the coverage of relevant issues. In fact, as Chaloka Beyani noted, "not all the laws and policies include an appropriate definition of an internally displaced person or clearly identify institutional responsibilities, and some address only a particular cause or stage of displacement, such as conflict or return, while others focus only on particular rights" 93 .

This suggests that, to some extent, domestic regulatory frameworks water down the scope of the Kampala Convention, particularly with respect to environmental IDPs due to slowonset disasters and climate change. However, to be consistent, this partial conclusion must first consider how deep and effective are the AU's efforts to establish and promote the disaster risk reduction strategies agenda in the continent.

Adopted in Nairobi on 16 April 2010, the Programme of Action for the Implementation of the Africa Regional Strategy for Disaster Risk Reduction (2006-2015) aimed to contribute to achieving sustainable development and eradicating poverty through a substantial reduction in the social, economic and environmental impact of disasters, including risks associated with climate change. It started by acknowledging the fact that disasters are occurring more often and thus the social and economic losses caused by them are increasing in Africa, which poses a great threat to Africa's ability to achieve sustainable development. Then, it stated that "disaster risk reduction (DRR) policies and institutional mechanisms do exist at various degrees of completeness in African countries. However, their effectiveness is limited. Hence a strategic approach to improving and enhancing their effectiveness and efficiency by emphasizing disaster risk reduction is needed" (emphasis added $)^{94}$.

In 2013, the Africa Position for the 4th Global Platform for Disaster Risk Reduction ${ }^{95}$, after taking note of ratification of the Kampala Convention that acknowledges the

\footnotetext{
${ }^{93} \mathrm{~A} / \mathrm{HRC} / 26 / 33$, p. 16.

94 AU, Programme of Action for the Implementation of the Africa Regional Strategy for Disaster Risk Reduction (2006-2015), Nairobi, 16 April 2010 online] (retrieved 9.12.2017).

${ }^{95}$ Held in Geneva, on 19-23 May, 2013.
} 
responsibilities of governments to protect people displaced by disasters and climate change and take measures to mitigate such displacement, recognizes the ongoing efforts to strengthen the monitoring, evaluation and reporting system for the Africa Regional Strategy and importance of verifiable reporting of disaster losses. In addition, it indicates that "Africa has developed an Africa Status Report for DRR, which is a detailed analysis of the state of disaster risk reduction in the region, based on national and sub-regional reports, summarizing achievements as well as emerging trends and challenges".

Launched in 2016 by the United Nations Office for Disaster Risk Reduction (UNISDR), the Disaster risk reduction in Africa: Status report (2015)" "examines risk drivers that exacerbate natural hazards' impacts on populations, and analyses the state of Africa's preparedness against the risk of disaster in relation to the Hyogo Framework for Action (HFA, 2005-2015)". After profiling the frequency, location and severity of natural hazards across Africa, the report found that this continent "holds half of the world's most riskprone countries, and is experiencing a rising number of disasters".

The report is organized around five indicators: the hazard and disaster impact profile of Africa, disaster risk drivers in Africa, status of Africa's implementation of the HFA, investment and financing for disaster risk reduction in Africa, and the transition from the HFA to the Sendai Framework for Disaster Risk Reduction. Its key findings include the following:

"Africa faces a huge challenge from climate change. About 22 African countries are highly vulnerable to climate change, often manifested through drought. Progress has been slow in the implementation of the Hyogo Framework for Action. (...) While DRR in Africa is being financed through national budget allocation, the private sector and international sources, it is clear more needs to be done. An immediate priority is to enhance the existing mechanisms and tools that measure progress in DRR, and review and assess risk baselines against the guidance contained in the Sendai Framework" (emphasis added).

The report concludes by stating that no tools have been set up to measure preparedness under the Sendai Framework for Disaster Risk Reduction (2015-2030). This aspect and all

\footnotetext{
${ }^{96}$ UNISDR, Disaster risk reduction in Africa: Status report (2015), 2016 [online] (retrieved 9.12.2017).
} 
of the above tell us much about the progress made to date, and also the long way to go to achieve the full implementation of both the Kampala Convention and the DRR regional agenda.

\section{CONCLUSION}

The purpose of the current paper was to assess to what extent the implementation of the African Union Convention for the Protection and Assistance of Internally Displaced Persons in Africa (Kampala Convention) is being effective with respect to persons displaced by environmental disasters in the context of climate change.

The answer to this seemingly simple question is far from straightforward. In fact, it involved three tasks: (i) provide an overview of the African context of internal displacement and identify the main provisions of the Convention on the protection of environmentally displaced persons; (ii) review the ongoing academic debate on the links between climate change and human mobility, as well as the evolution of the international legal and political system to address the protection needs of persons displaced by environmental disasters related to climate change; and (iii) analyze the process of transposition into domestic law and the implementation of the said convention, seeking to ascertain its effectiveness and impact on the protection of environmentally displaced persons.

After the journey, it is time to look back at the initial purpose and synthesize the main findings.

Acting as an amplifier of armed conflict and other elements of socio-economic vulnerability, anthropogenic climate change is becoming the most prevalent force inducing involuntary displacement. This real affirmation is particularly serious and alarming in Africa, the continent that, despite being the least polluting (representing only 3\% of global $\mathrm{CO} 2$ emissions), is the one that bears the greatest burden of global warming, since it is the most exposed to its harmful effects. Forced displacement of populations stands out among the most serious of these effects. The victims, environmentally displaced persons, are defined as all persons or groups of persons who have been obliged or forced to escape or flee their home or place of habitual residence for an indefinite period of time as a result of human-induced environmental disasters, including climate change, whether or not they have crossed an internationally recognized state border. It is clear that the vast majority of 
these people remain within their own countries. However, the magnitude of those crossing international borders, thus increasing the numbers of so-called "economic immigrants", should not be underestimated. It is a fact that, as a result of the interaction and mixed nature of the causes, it is becoming increasingly difficult to distinguish between environmentally displaced persons and those who are displaced for other reasons. Even so, while it is true that climate change will increasingly play a decisive role in human mobility, it is essential to move towards multilevel governance and political measures that favor obtaining knowledge of the real dimension of the problem and put an end to the invisibility and silencing of the human drama of the victims.

By using the term immigrant (understood as voluntary for economic reasons) and statutory refugee binomial for categorizing the actors of cross-border mobility, and due to the unwillingness to face their responsibility to protect the human rights of internally displaced persons, the international community, embodied in the UN, only deepens this invisibility and silencing of the victims of environmental displacement in the context of climate change, especially those displaced by slow-onset disasters. Unfortunately, the New York Declaration on Refugees and Migrants (2016) ${ }^{97}$ and the two Global Compacts in force, which are expected to be adopted in 2018, leave little room for hope.

In this international context, the Kampala Convention, with its lights and shadows, is good news, a sign of hope for the victims of environmental displacement and a commendable legislative example for the other regions and the international community as a whole. It does so insofar as it clearly establishes the responsibility of Governments, individually and cooperatively, to protect persons displaced due to human-induced environmental disasters, climate change included, and to take measures to prevent and mitigate this displacement.

Five years after it came into force, there are still challenges for its full implementation. Arguably, remarkable efforts have been made in this regard. However, its concrete impact on enhancing protection of and assistance to IDPs due to disasters and climate change is still unperceivable. Much needs to be done to achieve that disaster preparedness and disaster management laws are adopted, and ensure that existing laws on disaster preparedness are comprehensive in nature so that they encompass disaster risk reduction and management. Efforts are required to develop proactive strategies to prevent or minimize displacement and planned relocations, when appropriate, as well as to adopt pre-

${ }^{97} \mathrm{~A} / \mathrm{RES} / 71 / 1$. 
emptive internal migration, which should be based on sound national policies and used as a coping or adaptational mechanism in the case of slow-onset disasters, and durable solutions.

\section{BIBLIOGRAPHY}

ACNUR, Cambio climático, desastres naturales y desplazamiento humano: la perspectiva del ACNUR, 2009.

ADEOLA, Romola, "What does development-caused displacement look like in Africa?", IDMC, December 2016 [online].

ADEPOJU, Aderanti, "Migration Dynamics, Refugees and Internally Displaced Persons", UNAI, 20 September 2016 [online].

AFIFI, Tamer / WARNER, Koko, The Impact of Environmental Degradation on Migration Flows across Countries, UNU-EHS Working Paper 5, 2008.

AFRICAN UNION, "Explanatory Note on the African Union Convention for the Protection and Assistance of Internally Displaced Persons in Africa", 2009 [online].

AU, Programme of Action for the Implementation of the Africa Regional Strategy for Disaster Risk Reduction (2006-2015), Nairobi, 16 April 2010 online].

BATES, Diane C., "Environmental Refugees? Classifying Human Migrations Caused by Environmental Change", Population and Environment, Vol.23, Issue 5 (2002), p.465-477. BIROL, Fatih, "Global Energy Outlook and the Implications for Africa", presentation in Paris, 25 April 2012 [online].

BLACK, Richard, Environmental Refugees: Myth or Reality? New Issues in Refugee Research Working Paper No. 34, Geneva: UNHCR, 2001.

BOANO, Camillo / ZETTER, Roger / MORRIS, Tim, Environmentally displaced people Understanding the linkages between environmental change, livelihoods and forcedmigration, Refugee Studies Centre's Forced Migration Policy Briefings, University of Oxford, 2008.

BROWN, Oli, "El baile de las cifras", $R M F, \mathrm{n}^{\circ} 31$ (2008), pp.8-9. 
BURROUGHS, William J., Climate Change. A Multidisciplinary Approach, 2nd Edition, Cambridge: Cambridge University Press, 2007.

CASTLES, Stephen, Environmental change and forced migration: making sense of the debate, New Issues in Refugee Research, Working Paper 70, Geneva: UNHCR, 2002.

COHEN, Roberta / BRADLEY, Megan, "Disasters and Displacement: Gaps in Protection", International Humanitarian Legal Studies, Vol. 1 (2010), p.3.

DUARTE, Carlos. M. (Coord.) et al., Cambio global. Impacto de la actividad humana sobre el sistema Tierra, Madrid: CSIC, 2006.

EL-HINNAWI, Essam, Environmental Refugees, Nairobi: United Nations Environmental Programme, 1985.

FRC, Cambio climático y movilidad humana: punto de vista humanitario, 22 de abril 2009 [online].

FRITZ, Carolina, Climate Change and Migration: Sorting through Complex Issues without the Hype, Washington: Migration Policy Institute, 2010 [online].

GLOBAL PROTECTION CLUSTER, Regulatory Framework on Internal Displacement. Global, regional and national developments, May 2016 [online].

GMF, Report: Climate-induced migration growing problem for nations of all kind, Washington, 29 September 2010 [online].

GODREJ, Dinyar, El cambio climático, Barcelona: Intermón Oxfam, 2002.

GUTERRES, António, "Millions Aprooted. Saving Refugees and Displaceds", Foreign Affairs, 2008 [online].

HEINRICH BÖLL STIFTUNG, Climate Governance in Africa. Adaptation Strategies and Institutions, Cape Town: Unity Press, 2010.

HOMER-DIXON, Thomas, Environmental Scarcity and Global Security, Headline Series, №300, New York: Foreign Policy Association, 1993.

IASC, “Climate Change, Migration and Displacement: Who Will Be Affected?" Working Paper submitted to UNFCCC Secretariat by the informal group on Migration/Displacement and Climate Change of the Inter-Agency Standing Committee, 31 October 2008 [online]. 
IDMC, Africa report on internal displacement, Geneva, December 2016.

IDMC, Global estimates 2012. People displaced by disasters, Geneva: IDMC, May 2013.

IDMC, Global Report on Internal Displacement, Geneva, May 2017.

IDMC, The Kampala Convention One year on: Progress and prospects, Geneva, 2013.

IDMC, The Kampala Convention two years on: time to turn theory into practice. Briefing Paper, Geneva, 2014.

INGC, Main report: INGC Climate Change Report: Study on the impact of climate change on disaster risk in Mozambique, [Asante, K., Brito, R., Brundrit, G., Epstein, P., Fernandes, A., Marques, M.R., Mavume, A , Metzger, M., Patt, A., Queface, A., Sanchez del Valle, R., Tadross, M., Brito, R. (eds.)], Mozambique: INGC, 2009.

INTERNATIONAL REFUGEE RIGHTS INITIATIVE, Comparison of the Kampala Convention and the IDP Protocol of the Great Lakes Pact. A briefing note by the International Refugee Rights Initiative, January 2014 [online].

IPCC, Cambio climático 2007: Informe de síntesis. Contribución de los Grupos de trabajo I, II y III al Cuarto Informe de evaluación del Grupo Intergubernamental de Expertos sobre el Cambio Climático [Equipo de redacción principal: Pachauri, R.K. y Reisinger, A. (directores de la publicación)], Ginebra, 2007.

IPCC, Climate Change 2014: Synthesis Report. Contribution of Working Groups I, II and III to the Fifth Assessment Report of the Intergovernmental Panel on Climate Change [Core Writing Team, R.K. Pachauri and L.A. Meyer (eds.)], Geneva, 2014.

IPCC, First Assessment Report, Cambridge: Cambridge University Press, 1990.

JACOBSON, Jodi L., Environmental Refugees: A yardstick of habitability. Washington: Worldwatch Institute, 1988.

KÄLIN, Walter / SCHREPFER, Nina, Protecting People Crossing Borders in the Context of Climate Change. Normative Gaps and Possible Approaches, Geneva: UNHCR, Division of International Protection, 2012.

KÄLIN, Walter, Climate Change Displacement - A Challenge for International Law, Kolkata, Mahanirban Calcutta Research Group [online].

KÄLIN, Walter, The Climate Change - Displacement Nexus, Brookings, 2008 [online]. 
KNIVETON, Dominic / SCHMIDT-VERKERK, Kerstin / SMITH, Christopher / BLACK, Richard, Climate Change and Migration: Improving Methodologies to Estimate Flows, Geneva: IOM - Migration Research Series Paper No. 33, 2008.

LABANDEIRA, Xavier / LINARES, Pedro, «El Acuerdo de París sobre cambio climático», ICADE (2016), núm. 97, pp.11-19.

LACZCO, Franc / AGHAZARM, Christine (eds.), Migration, Environment and Climate Change: Assessing the Evidence, Geneva, 2009.

LECKIE, Scott, "Implicaciones sobre los derechos humanos", $R M F, \mathrm{n}^{\circ} 31$ (2008), pp.1819.

LONERGAN, Steve, "The Role of Environmental Degradation in Population Displacement”, Environmental Change and Security Project Report, Issue 4 (1998), pp.515.

MCADAM, Jane, Climate Change, Forced Migration and International Law, Oxford: Oxford University Press, 2012.

MORRISSEY, James, Environmental Change and Forced Migration. A State of the Art Review, Refugee Study Center's Background Paper, University of Oxford, 2009.

MORTON, Andrew / BONCOUR, Philippe / LACZKO, Frank, "Seguridad humana y desafíos Políticos”, $R M F, \mathrm{n}^{\circ} 31$ (2008), pp.5-7.

MOTAVAlLI, Jim, "Prólogo" a Motavalli, Jim (Comp.), El cambio climático. Crónicas desde las zonas de riesgo del planeta, Barcelona: Paidós, 2005.

MYERS, Norman / KENT, Jennifer., Environmental Exodus: An Emergent Crisis in the Global Arena, Washington DC: The Climate Institute, 1995.

Nansen Conference on Climate Change and Displacement in the 21st Century, Oslo, 6-7 June 2011 [online].

NASER, Mostafa M., "Climate Change-Induced Displacement: Definitional Issues and Concerns", Chicago-Kent Journal of Environmental and Energy Law, Vol. 2, Issue 1 (2011), pp.1-52.

PIGUET, Étienne / PÉCOUD, Antoine / GUCHTENEIRE, Paul de (eds.), Migration and Climate Change, Paris/Cambridge: UNESCO/Cambridge University Press, 2011. 
POTSDAM INSTITUTE FOR CLIMATE IMPACT RESEARCH AND CLIMATE ANALYTICS, Turn Down the Heat: Why a $4^{\circ} \mathrm{C}$ Warmer World Must Be Avoided, Washington D.C.: The World Bank, 2012.

RENAUD, Fabrice / BOGARDI, Janos J. / DUN, Olivia / WARNER, Koko, Control, Adapt or Flee. How to Face Environmental Migration?, Bonn: UNU-EHS, 2007.

RSH-OIM, El cambio climático, la degradación del medio ambiente y la migración: qué hacer ante las circunstancias de vulnerabilidad de la población y cómo aprovechar las oportunidades de solventar el problema. Informe de la Conferencia, Ginebra, 2008.

RUPPEL, Oliver C., "Climate Change Law and Policy Positions in the African Union and Related Developments in Selected African Countries", in Ruppel, Oliver C. / Roschmann, Christian / Ruppel-Schlichting, Katharina (Eds.), Climate Change: International Law and Global Governance Volume II: Policy, Diplomacy and Governance in a Changing Environment, Baden-Baden: Nomos, 2013, pp.411-448.

SANZ DONAIRE, Juan José, "Precisiones a las bases científicas del cambio climático", en Centro Superior De Estudios De La Defensa Nacional (Ed.), Cambio climático y su repercusión en la economía, la seguridad y la defensa, Madrid: Ministerio de Defensa, 2009.

SMITH, Lauren C., El mundo en 2050. Las cuatro fuerzas que determinarán el futuro de la civilización, Barcelona: Debate, 2011.

SOLÀ PARDELL, Oriol, Desplazados medioambientales: una nueva realidad, Bilbao: Universidad de Deusto, 2012.

STAL, Marc / WARNER, Koko, The Way Forward. Researching the Environment and Migration Nexus. Research Brief based on the Outcomes of the 2nd Expert Workshop on Climate Change, Environment, and Migration 23 - 24 July 2009, Munich, Germany. Bonn: UNU-EHS, 2009.

STAVROPOULOU, Maria, "Alterações climáticas: desastres naturais e deslocações forçadas", en: Refugiados e deslocados ambientais: o lado humano das alterações climáticas". Actas do IX Congresso Internacional do Conselho Português para os Refugiados, Lisboa: CPR, pp.36-38.

STEINER, Achim, "Prólogo" a la RMF, n³1 (2008), p.4. 
A. dos Santos Soares

RCDA Vol. IX Núm. 1 (2018): 1 - 48

UNISDR, Disaster risk reduction in Africa: Status report (2015), 2016 [online]. 